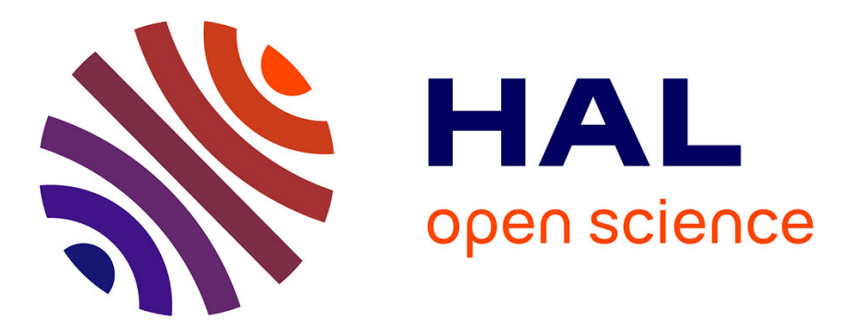

\title{
Manganese superoxide dismutase in breast cancer: From molecular mechanisms of gene regulation to biological and clinical significance
}

\author{
Philippe Becuwe, Marie Ennen, Rémi Klotz, Claire Barbieux, Stéphanie \\ Grandemange
}

\section{To cite this version:}

Philippe Becuwe, Marie Ennen, Rémi Klotz, Claire Barbieux, Stéphanie Grandemange. Manganese superoxide dismutase in breast cancer: From molecular mechanisms of gene regulation to biological and clinical significance. Free Radical Biology and Medicine, 2014, pp.77C:139-151. 10.1016/j.freeradbiomed.2014.08.026 . hal-01094585

\section{HAL Id: hal-01094585 \\ https://hal.science/hal-01094585}

Submitted on 5 Jan 2015

HAL is a multi-disciplinary open access archive for the deposit and dissemination of scientific research documents, whether they are published or not. The documents may come from teaching and research institutions in France or abroad, or from public or private research centers.
L'archive ouverte pluridisciplinaire $\mathbf{H A L}$, est destinée au dépôt et à la diffusion de documents scientifiques de niveau recherche, publiés ou non, émanant des établissements d'enseignement et de recherche français ou étrangers, des laboratoires publics ou privés. 
Review Article

\title{
Manganese superoxide dismutase in breast cancer: From molecular mechanisms of gene regulation to biological and clinical significance
}

\author{
Philippe Becuwe*, Marie Ennen, Rémi Klotz, Claire Barbieux, Stéphanie Grandemange \\ Centre de Recherche en Automatique de Nancy, UMR 7039 CNRS, Faculté des Sciences et Technologies, Université de Lorraine, 54506 Vandoeuvre-lès-Nancy \\ Cedex, France
}

\section{A R T I C L E I N F O}

\section{Article history:}

Received 4 June 2014

Received in revised form

21 August 2014

Accepted 21 August 2014

Available online 16 September 2014

\section{Keywords:}

MnSOD

Breast cancer

Gene regulation

Metastasis

Angiogenesis

Proliferation

Free radicals

\begin{abstract}
A B S T R A C T
Breast cancer is one of the most common malignancies of all cancers in women worldwide. Many difficulties reside in the prediction of tumor metastatic progression because of the lack of sufficiently reliable predictive biological markers, and this is a permanent preoccupation for clinicians. Manganese superoxide dismutase (MnSOD) may represent a rational candidate as a predictive biomarker of breast tumor metastatic progression, because its gene expression is profoundly altered between early and advanced breast cancer, in contrast to expression in the normal mammary gland. In this review, we report the characterization of some gene polymorphisms and molecular mechanisms of SOD2 gene regulation, which allows a better understanding of how MnSOD is decreased in early breast cancer and increased in advanced breast cancer. Several studies display the biological significance of MnSOD level in proliferation as well as in invasive and angiogenic abilities of breast tumor cells by controlling superoxide anion radical $\left(\mathrm{O}_{2}^{--}\right)$and hydrogen peroxide $\left(\mathrm{H}_{2} \mathrm{O}_{2}\right)$. Particularly, they report how these reactive oxygen species may activate some signaling pathways involved in breast tumor growth. Emerging understanding of these findings provides an interesting framework for guiding translational research and suggests a way to define precisely the clinical interest of MnSOD as a prognostic and/or predicting marker in breast cancer, by associating with some regulators involved in SOD2 gene regulation and other well-known biomarkers, in addition to the typical clinical parameters.
\end{abstract}

(c) 2014 Elsevier Inc. All rights reserved.

\section{Contents}

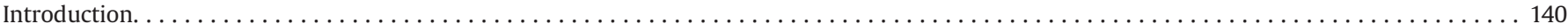

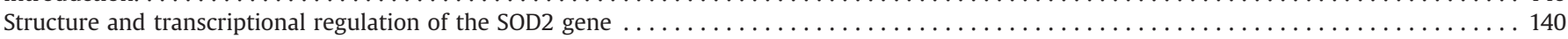

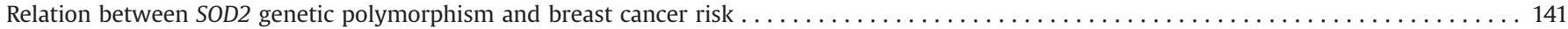

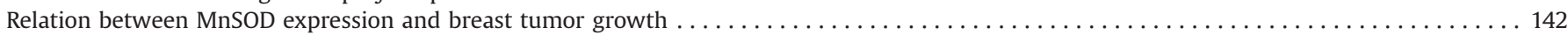

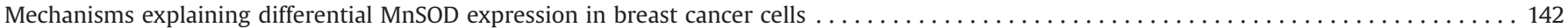

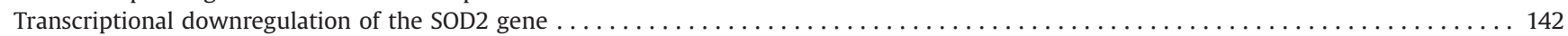

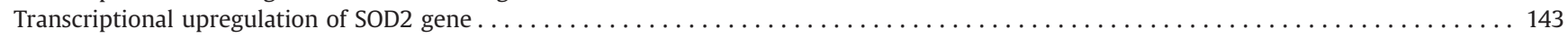

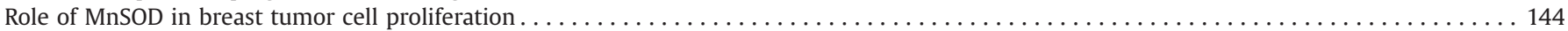

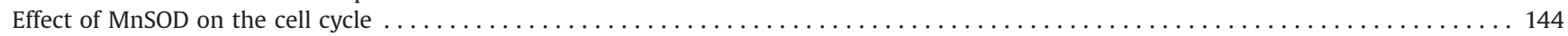

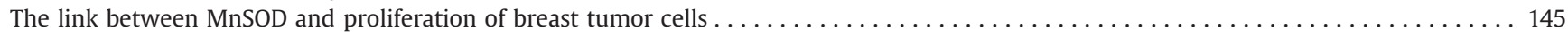

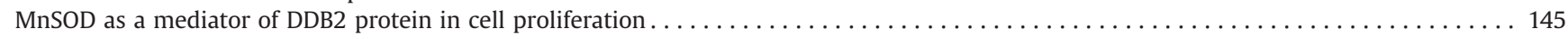

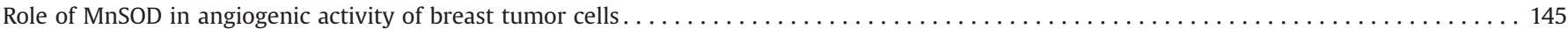

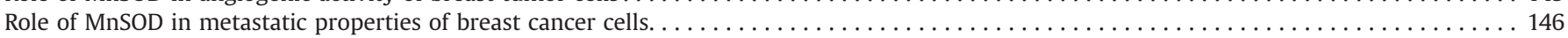

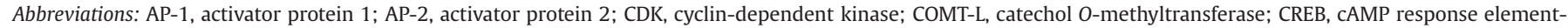

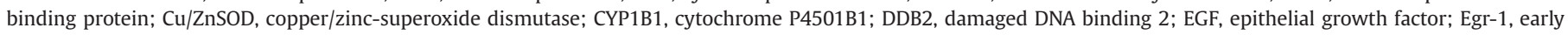

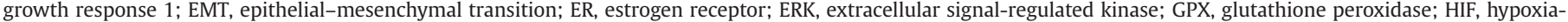

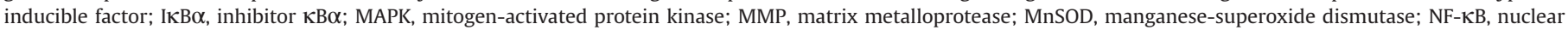
factor-КB; Nox, NADPH oxidase; NPM, nucleophosmin; PHD, prolyl-hydroxylase; PKB/Akt, protein kinase B; PTEN, phosphatase and tensin homolog deleted from chromosome 10; ROS, reactive oxygen species; Sp1, specific-1; VEGF, vascular endothelial growth factor.

* Corresponding author.

E-mail address: philippe.becuwe@univ-lorraine.fr (P. Becuwe). 


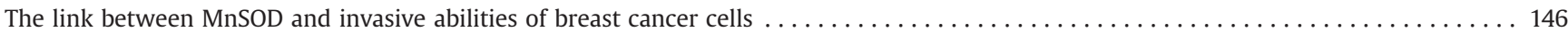

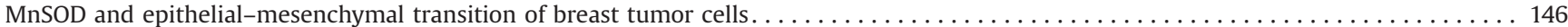

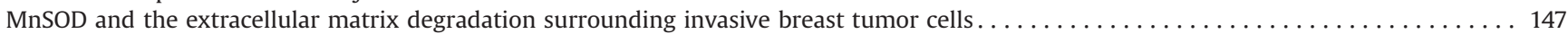

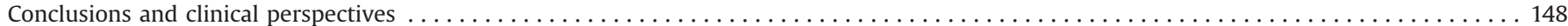

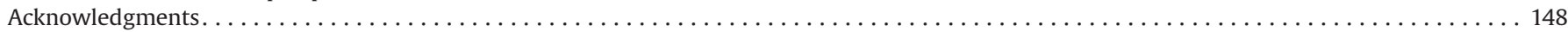

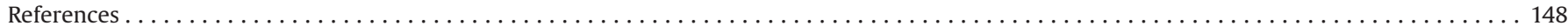

\section{Introduction}

Today breast cancer represents the most frequent of all cancer pathologies in the world, with more than 1 million newly diagnosed cases and about 373,000 cancer-related deaths in women each year, despite all the significant progress in its diagnosis and treatment. Molecular mechanisms leading to growth and metastasis progression of breast tumors have not been clearly identified. In addition, a number of risk factors such as reproductive and hormonal factors, alcohol consumption, tobacco smoke, dietary factors, and chronic inflammation have been identified for breast cancer, but the mechanisms by which they increase the risk of the disease are not always clear [1]. It has been proposed that the production of reactive oxygen species (ROS) leading to oxidative stress is the linking factor between these carcinogens. Whereas high levels of ROS participate in the genetic instability leading to the multistep process of carcinogenesis, they also contribute to breast cancer progression, by activating various signaling pathways and redoxsensitive transcription factors in tumor cells, which regulate angiogenesis, proliferation, and metastasis [2].

ROS, such as superoxide anion radical $\left(\mathrm{O}_{2}^{\bullet-}\right)$, hydrogen peroxide $\left(\mathrm{H}_{2} \mathrm{O}_{2}\right)$, or hydroxyl radical $\left(\mathrm{OH}^{\bullet}\right)$, are formed as a by-product of several cellular processes, particularly the electron transport chain in mitochondria, as well as environmental exposure [3]. The levels of $\mathrm{O}_{2}^{--}$and $\mathrm{H}_{2} \mathrm{O}_{2}$ are also determined by the balance between ROSgenerating and antioxidant systems in cancer cells [4]. In this review, the origin and role of $\mathrm{O}_{2}^{--}$and $\mathrm{H}_{2} \mathrm{O}_{2}$ will be limited to the breast tumor growth and not to the early mutagenic events leading to cell transformation.

In the case of breast cancer, $\mathrm{O}_{2}^{--}$and $\mathrm{H}_{2} \mathrm{O}_{2}$ may be generated particularly from estrogen metabolism through catechol estrogen redox cycling [5]. In addition, changes in the expression of antioxidant enzymes, leading to an imbalance between them, have often been observed in breast cancer cells, compared to noncancerous cells [6]. Among them, the manganese-dependent superoxide dismutase (MnSOD) is well known to have an altered expression in breast cancer, as in many other cancers [7-13]. This mitochondrial enzyme possesses a typical mitochondrial leader sequence in the $\mathrm{N}$-terminal region allowing the apoprotein to be translocated rapidly into the matrix of the organelle and to convert mitochondrial-generated $\mathrm{O}_{2}^{\bullet-}$ from the respiratory chain to $\mathrm{H}_{2} \mathrm{O}_{2}[14,15]$. In contrast to cytosolic and extracellular $\mathrm{Cu} / \mathrm{ZnSOD}$ expressed also in human cells, MnSOD is considered one of the most important antioxidant enzymes, because MnSOD-knockout mice have severe metabolic acidosis and degeneration of neurons and cardiac myocytes and die prenatally from dilated cardiomyopathy [16]. This antioxidant enzyme is cytoprotective and plays an antiapoptotic role against oxidative stress, ionizing radiation, and inflammatory cytokines $[17,18]$.

Transformation of breast epithelial cells is a multistep process in which ROS are involved and may be exacerbated by a low intracellular MnSOD activity, which depends on SOD2 genetic polymorphisms. Among other SOD isoforms, these identified genetic polymorphisms may be associated with a predisposition to a greater risk of breast cancer [19].

In contrast to normal cells, MnSOD expression is often altered at the transcriptional level in breast tumors and cancer cell lines. This alteration in MnSOD expression is often associated with that of $\mathrm{H}_{2} \mathrm{O}_{2}$-detoxifying enzymes in breast tumor cells, leading to an imbalance in the redox state by an increase in the level of $\mathrm{O}_{2}^{--}$or $\mathrm{H}_{2} \mathrm{O}_{2}$ and its consequences on tumor growth [6]. Also, this review intends to provide a comprehensive picture of MnSOD and the regulation of its gene for a better understanding of how this antioxidant enzyme plays a role in breast tumor growth and may have a clinical interest.

\section{Structure and transcriptional regulation of the SOD2 gene}

MnSOD expression, which is encoded by the nuclear SOD2 gene located on chromosome 6q25, is inducible by many transcription factors able to bind the proximal promoter and highly regulated in normal cells $[20,21]$. The SOD2 gene consists of five exons interrupted by four introns and characterized by a 5'-proximal promoter lacking a TATA or CAAT box but containing a GC-rich region [22]. Regulatory regions of the SOD2 gene are divided into numerous upstream regulatory elements, the GC-rich region (core promoter), and an enhancer in the second intron (Fig. 1). Multiple transcription factor binding sites have been localized and characterized in these regulatory regions. Nuclear factor- $\kappa \mathrm{B}(\mathrm{NF}-\kappa \mathrm{B}), \mathrm{CAAT} / \mathrm{enhancer}$ binding protein, and nuclear factor 1 transcription factors are involved in the upregulation of the SOD2 gene in response to numerous stimuli

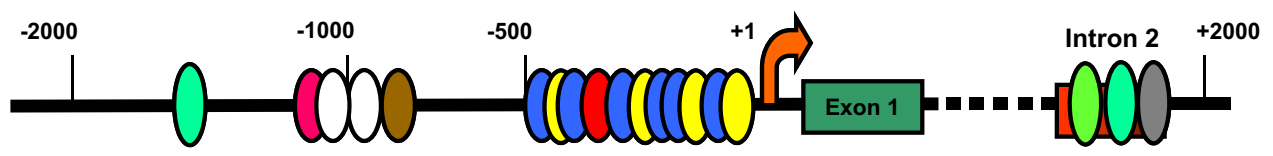

Upstream elements

GC-rich region

Intronic enhancer

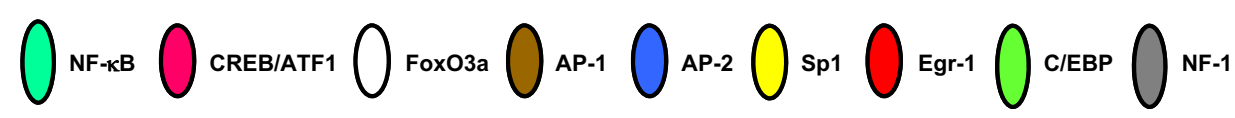

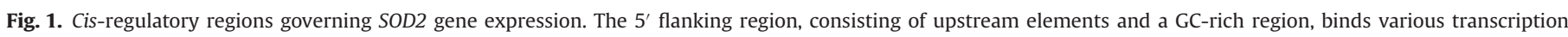

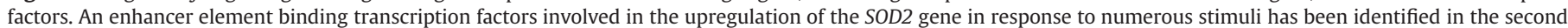
intron. Negative and positive numbers indicate the locations of these cis-regulatory regions relative to the transcription start site, which is designated +1 . 
such as cytokines, by binding their enhancer element localized in the second intron [23-25]. The possibility of the CCCTC binding factor binding to this intronic enhancer has been recently suggested, but without demonstration of its direct involvement in the regulation of SOD2 gene [26]. Two functional binding sites, one for activator protein 1 (AP-1), a heterodimer consisting of c-Fos and c-Jun proteins, and another for the cAMP response element-binding protein (CREB) associated with the CREB-related activating transcription factor 1, have been identified in the SOD2 gene promoter and play positive roles in inducing MnSOD transcription under stimulating conditions such as growth factors or phorbol esters [27]. This explains how the SOD2 gene is induced by the protein kinase $\mathrm{C}$ or p38 mitogen-activated protein kinase (MAPK)-dependent signaling pathway $[28,29]$. In addition, FoxO transcription factors belonging to the forkhead family of transcriptional regulators may regulate MnSOD transcription through a specific and wellcharacterized FoxO binding element found in the SOD2 gene promoter [30]. Finally, the proximal SOD2 gene promoter exhibits also the presence of a GC-rich region containing multiple binding sites for various transcription factors, such as specific-1 (Sp1), activator protein 2 (AP-2), and early growth response 1 (Egr-1) [31,32]. It has been demonstrated that Sp1, a zinc-finger transcription factor, is essential for basal transcription of the SOD2 gene in several cell lines. On the other hand, AP-2 is involved in the decrease in basal transcription of the SOD2 gene, as well as in normal and some cancer cell lines, by interfering with Sp1 binding to the proximal promoter [32,33]. In addition, Egr-1 has been demonstrated to activate MnSOD transcription by binding to its specific site in the proximal promoter, in response to plateletderived growth factor [34].

Coactivators may be associated with transcription factors to enhance the transcription of the SOD2 gene. Recently, nucleophosmin (NPM), an RNA-binding protein, has been identified as a coactivator of SOD2 gene transcription by integrating Sp1 and $\mathrm{NF}-\kappa \mathrm{B}$ responses. NPM binds to an $11-\mathrm{G}$ single-strand loop structure in the unique GC-rich region of the proximal SOD2 promoter and forms a complex with $\mathrm{Sp} 1$ and $\mathrm{NF}-\kappa \mathrm{B}$, mediating the interaction of promoter and enhancer to stimulate transcription $[35,36]$.

It may be noted that a sequence analysis of the $5^{\prime}$ flanking region of the SOD2 gene has predicted some other binding sites, particularly for p53 and nuclear factor-E2-related transcription factor, but their direct involvement in the regulation of this gene has not been clearly identified [37,38].

Previous studies have contributed to showing that the epigenetic process, such as methylation of $\mathrm{CpG}$ islands and posttranslational modifications of histones, may explain the low MnSOD expression in proliferative cells. The SOD2 gene can be transcriptionally repressed by aberrant hypermethylation at a cytosine localized in the enhancer element of intron 2 and the upstream element between -580 and -1350 , but not in the GC-rich region, containing a high density of CpG islands [39]. Transcriptional regulation of the SOD2 gene may be mediated by the level of acetylated and methylated histones. Briefly, hypoacetylation of histones is associated with low SOD2 gene expression, because of a condensed chromatin structure, which decreases the accessibility of transcription factors to their respective binding sites. On the other hand, hyperacetylation of histones is directly correlated with MnSOD expression after induction of the SOD2 gene [40].

\section{Relation between SOD2 genetic polymorphism and breast cancer risk}

Even if $\mathrm{O}_{2}^{--}$is not an especially reactive agent itself, it serves for the generation of other ROS such as $\mathrm{H}_{2} \mathrm{O}_{2}$ and peroxynitrite. Cells need antioxidant enzymes to remove $\mathrm{O}_{2}^{--}$and $\mathrm{H}_{2} \mathrm{O}_{2}$ to avoid deleterious effects that can promote cell transformation. Also, low MnSOD activity, depending on SOD2 genetic polymorphisms, may contribute to the breast carcinogenesis process. From a large number of studies in diverse populations, a relation between low MnSOD activity and risk of breast cancer development has been observed.

Two main SOD2 genetic polymorphisms have been identified. The first is the Ile-to-Thr amino acid change at codon 58, promoting lower MnSOD activity due to destabilization of the tetrameric structure of the antioxidant enzyme. This change in the amino acid sequence does not prevent each monomer of MnSOD from being translocated into the mitochondrial matrix. However, its frequency seems to be too low to have any detectable effect on breast cancer risk [1]. Other polymorphisms have been identified in the SOD2 gene promoter [41]. The most commonly studied polymorphism of the SOD2 gene is a single nucleotide substitution of $\mathrm{C}$ to $\mathrm{T}$ at the second nucleotide of codon 16 of the SOD2 gene, encoding an amino acid substitution from alanine (GCT) to valine (GTT) at position 9 of the mitochondrial targeting sequence of the mature protein. This alteration, designated as the MnSOD Ala ${ }^{16}$ Val polymorphism, has been found to affect the transport of MnSOD into the mitochondria, thus altering its enzymatic activity. Whereas the Ala form of MnSOD is targeted into the mitochondria, the Val form is partially arrested in the inner mitochondrial membrane. Related to this, the human MnSOD Val variant has been found to generate $30-40 \%$ less active MnSOD protein compared to the Ala variant in mitochondria $[42,43]$. The SOD2 Val/Val genotype, having a low MnSOD activity as a consequence, could be considered deleterious for mammary epithelial cells exposed to environmental carcinogens such as alcohol, tobacco smoke, or estrogens generating $\mathrm{O}_{2}^{\bullet-}$ during their metabolism [19].

The Ala ${ }^{16}$ Val polymorphism has been most widely studied in relation to breast cancer risk. In summary, breast cancer risk is slightly increased in women carrying the SOD2 Ala/Ala genotype compared to those carrying the Val/Val genotype, especially in premenopausal women. However, an apparent breast cancer risk was increased in younger women with the SOD2 Val allele compared to those with the SOD2 Ala/Ala genotype [44]. This risk is further increased in premenopausal women with low intake of fruit, vegetables, and various dietary supplements (antioxidant vitamins and selenium). Some other epidemiologic studies have revealed a relation between this Ala/Ala genotype and smoking, alcohol consumption, oral contraceptives, and hormone replacement therapy (for postmenopausal women) in diverse populations [45,46].

Recently, an epidemiological study on a large population of patients focused on examining associations between combined gene polymorphisms in antioxidant enzymes and breast cancer risk. An increase in the risk of breast cancer has been observed particularly in patients who carry both the SOD2 Ala/Ala genotype and the glutathione peroxidase 1 (GPX-1) Pro ${ }^{198}$ Leu genotype (genetic polymorphism at codon 198, resulting in either proline or leucine), whereas neither allele alone shows any change in breast cancer risk [47]. Whereas MnSOD dismutates $\mathrm{O}_{2}^{\bullet-}$ to $\mathrm{H}_{2} \mathrm{O}_{2}$, GPX-1 is involved in detoxifying $\mathrm{H}_{2} \mathrm{O}_{2}$ to $\mathrm{H}_{2} \mathrm{O}$ depending on glutathione (GSH) and the GSH redox cycle by glutathione reductase [48]. The selenium-dependent activity of the GPX-1 Pro ${ }^{198}$ Leu mutant enzyme is lower than for the GPX- 1 Pro ${ }^{198}$ wild-type enzyme $[49,50]$. No significant association was observed between common variants in genes encoding other antioxidant enzymes (catalase, $\mathrm{Cu} / \mathrm{ZnSOD}, \mathrm{GPX}-4$, and thioredoxin system) and SOD2 genetic polymorphism in susceptibility to breast cancer [51].

Another interaction between SOD2 and genes encoding enzymes involved in the metabolism of catecholamines and catecholestrogens and producing $\mathrm{O}_{2}^{\bullet-}$, such as catechol $\mathrm{O}$-methyltransferase (COMT-L) and cytochrome P4501B1 (CYP1B1), has been studied with some risk factors. The risk of developing breast cancer was increased in patients 
with a body mass index $(\mathrm{BMI})>24 \mathrm{~kg} / \mathrm{m}^{2}$ or high alcohol consumption and carrying the SOD2 Ala allele combined with COMT-L and CYP1B1 genotypes [52,53]. These results may be related to the significant association found between the SOD2 Ala allele and postmenopausal use of estrogens in the increase in breast cancer risk [54].

In the literature, some studies have identified conflicting roles for this SOD2 genetic polymorphism and breast cancer risk. Among them, some clinical studies reported no association in American women between $\mathrm{Ala}^{16} \mathrm{Val}$ polymorphism and breast cancer risk, when other risk factors were taken into account, such as high BMI, smoking, alcohol, and menopausal status [55,56]. In addition, recently no evidence for association of the SOD2 genetic polymorphism with postmenopausal breast cancer risk was found in a large German population [57].

Most studies were limited to an association between the polymorphism and cancer initiation without analyzing the relation with cancer progression. One study compared two female breast cancer groups according to positive and negative lymph nodes with the SOD2 genetic Ala ${ }^{16}$ Val polymorphism. The results described an association between the SOD2 Val/Val genotype and the breast cancer group with positive lymph nodes, suggesting a relationship between low MnSOD activity and invasive breast cancer [58]. Even if the SOD2 Val/Val genotype was not combined with gene polymorphisms of other antioxidant enzymes, the authors of this study explained their results as a decrease in the ability to detoxify $\mathrm{O}_{2}^{--}$and $\mathrm{H}_{2} \mathrm{O}_{2}$, which is known to be involved in carcinogenesis as well as tumor progression [2]. These results are opposite to those we observed in breast cancer cell lines [6] and a polymorphism identified in the SOD2 gene promoter, corresponding to a single-nucleotide substitution of $\mathrm{C}$ to $\mathrm{T}$ at position -102 from the start site of transcription [41]. This polymorphism, which leads to a 50\% reduction in transcriptional activity of the SOD2 gene by changing the binding pattern of the AP-2 transcription factor, has been associated with a progression-free and relapse-free survival of patients because of a less important progression of breast cancer toward metastasis and also effective chemotherapy and radiation therapy [59].

\section{Relation between MnSOD expression and breast tumor growth}

Altered MnSOD levels have been found in many cancer cells from the early stage of carcinogenesis. Increased or decreased levels of MnSOD have been reported in tumor cells, compared to their normal counterparts, which depends on cancer type and tumor grade [7-13]. Concerning breast cancer, MnSOD is differentially expressed in tumor cell lines as well as in tumor samples from patients. We observed that this distinct MnSOD expression is dependent on estrogen receptor (ER) status and the invasive abilities of breast tumor cells. The estrogen-sensitive and nonmetastatic breast tumor MCF-7 and T47D cell lines exhibit a low basal expression of MnSOD, in contrast to nontransformed and normal breast epithelial cells such as MCF-10A and HMEC [6,60]. On other hand, the estrogen-independent and metastatic breast cancer MDAMB231 and SKBR3 cell lines exhibit a high basal MnSOD expression correlating with their invasive and metastatic properties, in contrast to normal epithelial and nonmetastatic cells.

Only two main studies have investigated MnSOD expression level in clinical breast tumor samples. One of them established a significant direct correlation of MnSOD expression and histological grading after immunohistochemistry in a cohort of 101 patients with primary invasive breast carcinoma. These results showed that significantly higher MnSOD levels were found in poorly differentiated compared to well-differentiated breast tumors. However, no relation was established between MnSOD and the presence of metastatic lymph nodes [61]. Associated with these results, an inverse correlation between immunohistochemical expression of
MnSOD and Ki67 was observed in breast carcinomas, but not with proliferating cell nuclear antigen or MIB-1 [62]. Taking into account these in vitro as well as in vivo results, we can conclude that high basal MnSOD expression is associated with invasive and metastatic properties of breast tumors, as already observed for brain tumors [9], gastric cancers, and colorectal cancers [12,63]. On the other hand, low basal MnSOD expression is accompanied rather by a high proliferative rate of breast tumor cells, as already observed for mesothelioma and prostate cancer cells $[64,65]$.

\section{Mechanisms explaining differential MnSOD expression in breast cancer cells}

\section{Transcriptional downregulation of the SOD2 gene}

Breast cancer cells display altered basal transcription of the SOD2 gene, which may be either upregulated or repressed in tumor cells, depending on the malignant phenotype. It has been described that the downregulated expression of the SOD2 gene in cancer cells may be due, in part, to defects in transcriptional regulation of the gene, because of mutations in the proximal promoter [41], epigenetic processes [26], or high expression of repressive transcription factors [33]. Some molecular mechanisms responsible for the transcriptional regulation of the SOD2 gene have been well defined in breast tumor cells, regarding mainly the proximal promoter, which is responsible for basal transcription of the SOD2 gene in many cancer cell lines.

Two molecular mechanisms have been identified as involved in low basal MnSOD expression in nonmetastatic breast cancer cells. This downregulated expression of the SOD2 gene may be attributable to either epigenetic mechanisms or an overexpression of repressors, leading to a defect in transcriptional regulation. In breast cancer, mutations in the proximal promoter or deletions of part of the regulatory region of the SOD2 gene responsible for altered MnSOD expression have been excluded. Some mutations have been identified, particularly in the GC-rich region of the proximal promoter, in several cancer cell lines, except in breast tumor cell lines (MCF-7, T47D, MDAMB231, and MDA-MB435). These mutations cause a repression of the SOD2 gene by changing the pattern of transcription factor binding, as for AP-2, which has additional binding sites [41]. Treatment of lowMnSOD-expressing breast cancer cell lines (MDA-MB435 and UACC 893) with the inhibitor of DNA methyltransferases, 5-azadeoxycytidine, restored SOD2 gene expression to the level of that observed in the immortalized breast epithelial MCF-10A cell line. Analysis after bisulfite modification of genomic DNA revealed that the SOD2 gene promoter was aberrantly hypermethylated at cytosines localized between -1361 and -1194 in the breast cancer cells, in contrast to MCF-10A cells. Interestingly, methylation of cytosine -1336 prevented CREB from binding to its recognition site previously identified [27] and attenuated not only the basal MnSOD expression but also the response of breast tumor cells to phorbol esters [66]. This hypermethylation of the SOD2 gene promoter to low basal MnSOD expression has been associated with hypoacetylated histones $\mathrm{H} 3$ and $\mathrm{H} 4$ at lysines 9 and 8 (H3K9 and H4K8), respectively, consistent with the treatment of lowMnSOD-expressing breast cancer cell lines with histone deacetylase inhibitors, such as trichostatin A or sodium butyrate, which reactivated SOD2 gene expression. In addition, the condensed chromatin structure was strengthened in low-MnSOD-expressing breast cancer cell lines by lower levels of methylated H3K4 [67].

The epigenetic process, particularly the hypermethylation of the SOD2 gene promoter, is not the one mechanism explaining the defect in transcriptional regulation of the SOD2 gene in breast cancer cells. We observed no changes in MnSOD mRNA levels in the MCF-7 and T47D cell lines treated with inhibitors of DNA methyltransferases [68]. In these breast tumor cell lines, we have demonstrated that the defect 
A
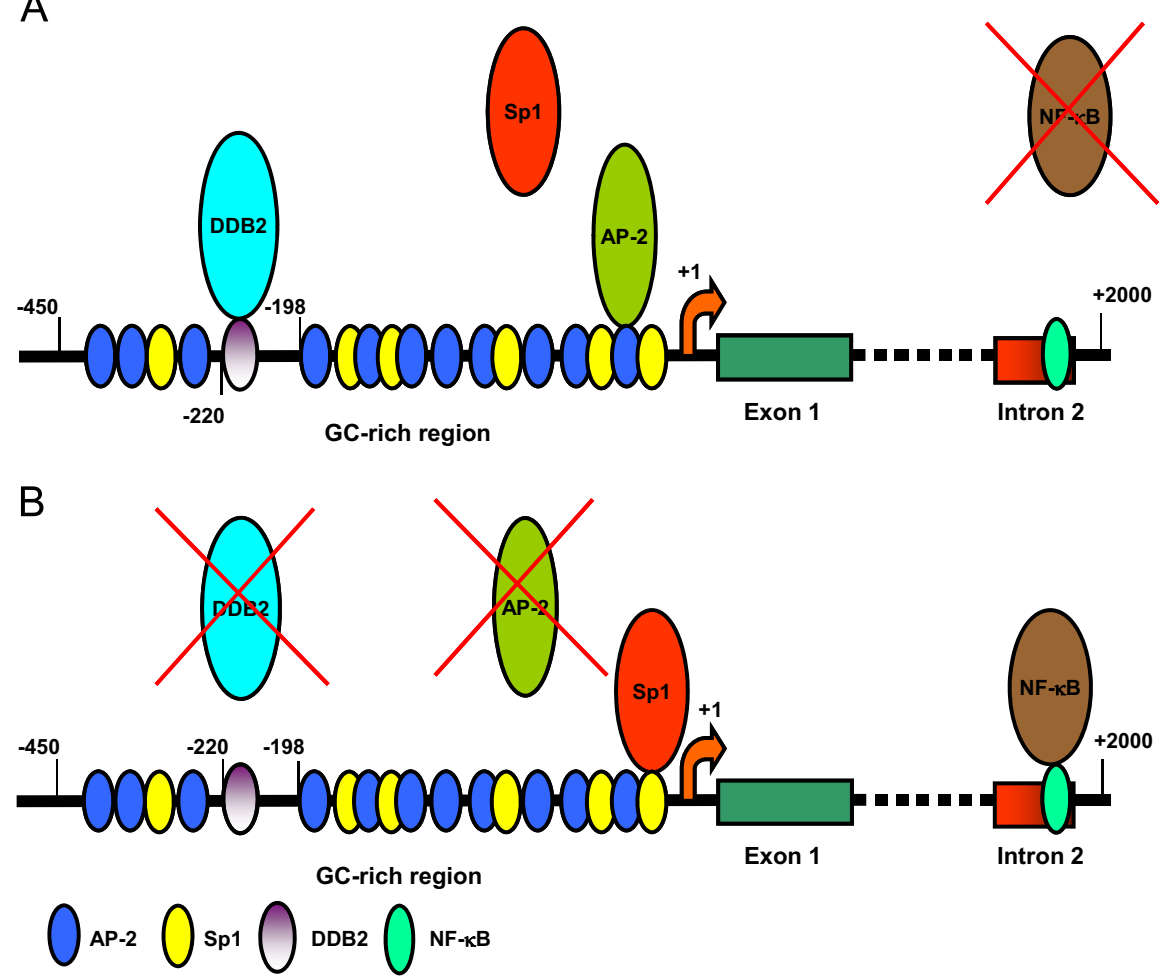

Exon 1

Intron 2

C
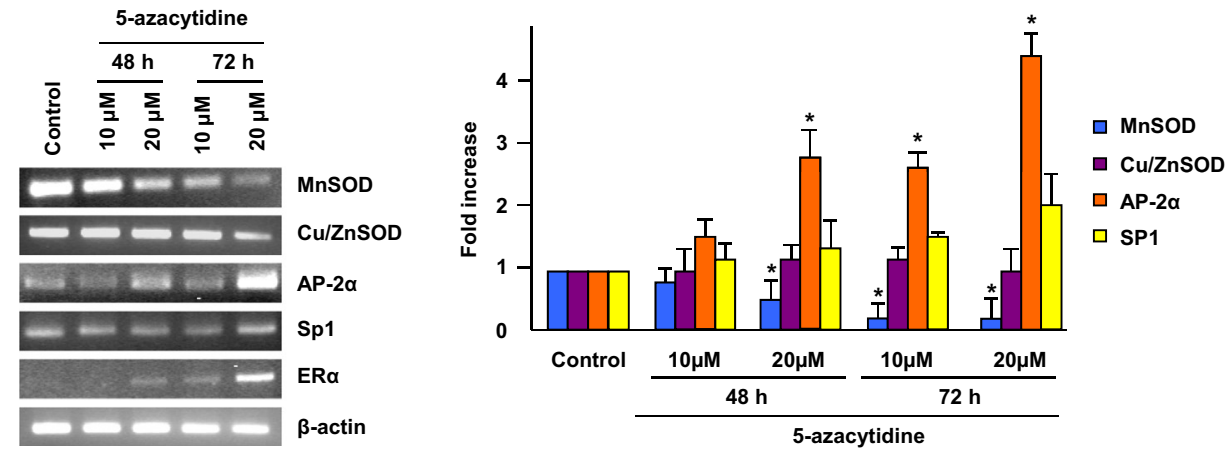

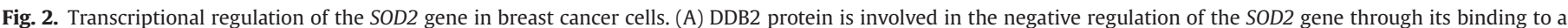

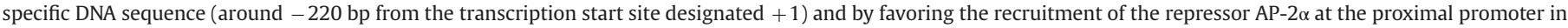

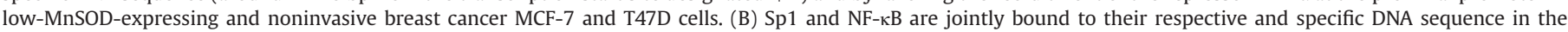

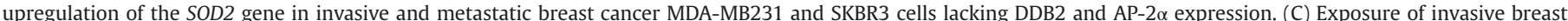

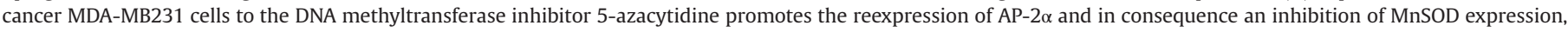

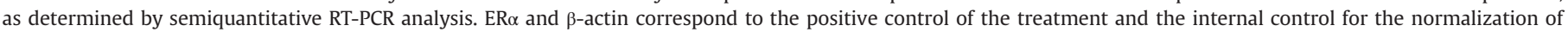
mRNA levels, respectively.

in transcriptional regulation of the SOD2 gene may be due to the occupancy of the proximal SOD2 promoter by the well-known transcription factor AP-2 $\alpha$, and the newly identified damaged DNA binding 2 (DDB2) protein. Both these proteins are overexpressed in low-MnSOD-expressing and nonmetastatic breast cancer cells [69,70]. AP-2 $\alpha$ has been described as a repressor of the SOD2 gene [33]. DDB2 was characterized originally as a component of the damage-specific DNA-binding heterodimeric complex DDB, which plays a role in nucleotide excision repair of UV-induced DNA lesions [71,72]. Mutations in the $D D B 2$ gene are associated with the autosomal recessive disease xeroderma pigmentosum group $\mathrm{E}$ corresponding to a defect in the repair of UV-induced DNA lesions [73]. Our research group has demonstrated for the first time that DDB2 may also influence transcription of genes by its binding to a specific DNA sequence in the proximal promoter of target genes $[68,74]$, in addition to its role in chromatin remodeling during the nucleotide excision repair process [75]. In the case of the SOD2 gene, DDB2 acts negatively on basal
MnSOD expression in breast cancer cells by binding to a specific and well-characterized DNA sequence localized in the GC-rich region (at $-220 \mathrm{bp}$ from the transcription start site), which promotes, downstream, the recruitment of the repressor AP- $2 \alpha$ at its respective binding sites, but not $\mathrm{Sp} 1$. In addition, this mechanism is associated with hypoacetylation of histones at the proximal promoter, exon 1 , and the intronic enhancer element of the SOD2 gene, which is consistent with low MnSOD expression [68]. This molecular mechanism of SOD2 gene regulation is depicted in Fig. 2A.

\section{Transcriptional upregulation of SOD2 gene}

Mechanisms underlying upregulation of the SOD2 gene in cancer cells remain largely unknown, in contrast to downregulation. However, we identified recently one mechanism, by which metastatic breast cancer cells exhibit a high basal MnSOD expression, which involves essentially the transcription factors Sp1 and NF- $\kappa B$ (Fig. 2B). We 


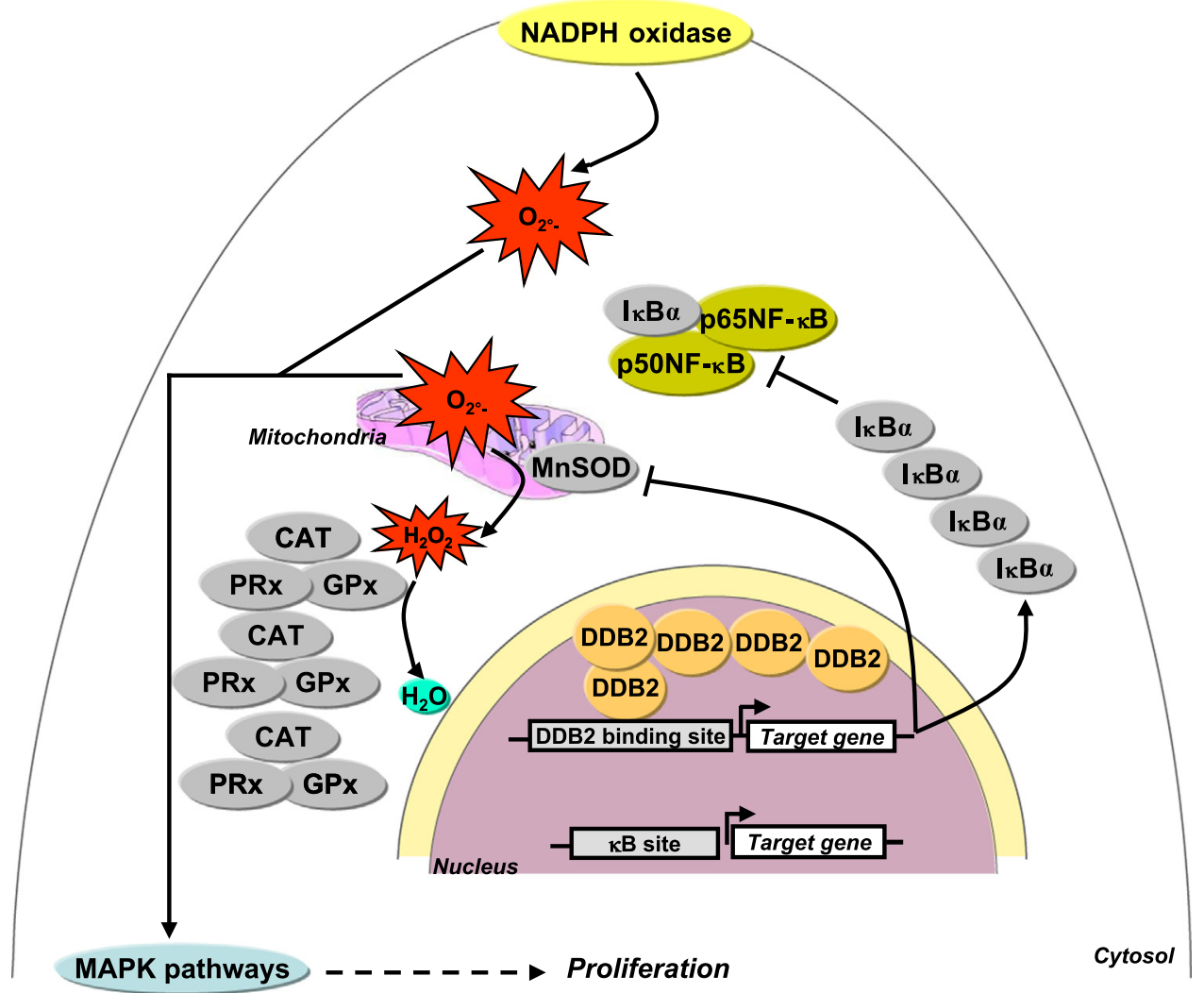

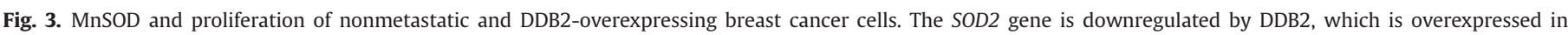

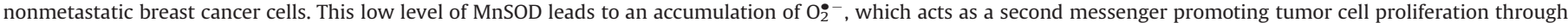

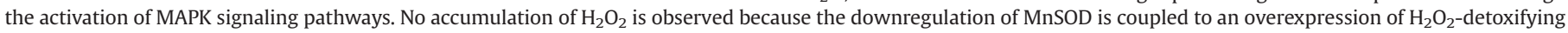
enzymes. The SOD2 gene is downregulated also by the DDB2-dependent upregulation of $\mathrm{I} \kappa \mathrm{B} \alpha$, which keeps NF- $\mathrm{kB}$ in an inactive form in the cytosol.

demonstrated that Sp1 binds to the GC-rich region of the proximal promoter, the specific DNA sequence localized precisely just before the transcription start site of the SOD2 gene. At the same time, we observed the binding of NF- $\kappa B$ interacting with its respective binding site in the intronic enhancer element [76] and which could cooperate with Sp1 through the RNA-binding protein NPM as mentioned above [36]. The binding of both these transcription factors is associated with hyperacetylation of histones $\mathrm{H} 3$ and $\mathrm{H} 4$, favoring the transcription of the SOD2 gene [76].

Interestingly, the Sp1- and NF- $\mathrm{KB}$-dependent upregulation of the SOD2 gene is strongly linked to the lack of DDB2 and AP- $2 \alpha$ expression in high-MnSOD-expressing and metastatic breast tumor cells. It has been shown that the loss of AP- $2 \alpha$ expression in these breast cancer cells is mediated by an epigenetic mechanism corresponding to a hypermethylation of CpG islands localized in the promoter as well as in exon 1 of the gene [69]. We confirmed that AP-2 $\alpha$ expression was restored after treatment of MDA-MB231 cells with an inhibitor of DNA methyltransferase, promoting a decrease in MnSOD mRNA levels (Fig. 2C). Also, there is no competition between $\mathrm{Sp} 1$ and $\mathrm{AP}-2 \alpha$ at their respective binding site on the proximal SOD2 gene promoter in high-MnSODexpressing breast tumor cells. Whereas Sp1 is expressed constitutively in all breast cancer cells, NF- $\kappa \mathrm{B}$ is activated constitutively only in metastatic breast cancer cells, characterized often as a p50/ p65 complex $[76,77]$. NF- $\kappa B$ may be activated constitutively by various molecular mechanisms in metastatic breast cancer cells: (i) aberrant expression of inhibitor $\kappa \mathrm{B}(\mathrm{I} \kappa \mathrm{B})$ kinase and casein kinase II, controlling the stability of the cytoplasmic I $\kappa B \alpha$ of NF- $\kappa B$ [78]; (ii) enhanced expression of NF- $\kappa \mathrm{B}$-inducing kinase activating IKB kinases, resulting in an epigenetic alteration of its gene [79]; and (iii) the growth factor-dependent signaling pathway via

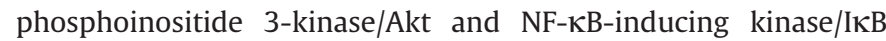
kinase [80]. However, we identified recently another original mechanism, showing that DDB2 is linked to constitutive NF- $\kappa \mathrm{B}$ activity in low-MnSOD-expressing breast cancer cells by upregulating $I \kappa B \alpha$ gene expression, through its binding to a specific DNA sequence located in the proximal promoter of this gene [74]. This mechanism is represented in Fig. 3.

\section{Role of MnSOD in breast tumor cell proliferation}

\section{Effect of MnSOD on the cell cycle}

In addition to the fact that cell cycle progression of proliferative normal cells is strictly regulated by a sequential activation of cyclindependent kinases (CDKs), regulated by CDK inhibitors, MnSOD may be considered a novel regulator of the cell cycle. Its expression changes during cell cycle progression. In addition, MnSOD expression is lower in highly proliferative normal cells than in quiescent or differentiated cells. It has been observed recently in mouse embryonic fibroblasts that changes in cell cycle transition time are tightly associated with MnSOD and $\mathrm{ROS}\left(\mathrm{O}_{2}^{--}\right.$and $\left.\mathrm{H}_{2} \mathrm{O}_{2}\right)$ levels. Transcription of the SOD2 gene is regulated differently according to the stage of the cell cycle, which could explain lower MnSOD expression during the $\mathrm{S}$ and $\mathrm{G} 2 / \mathrm{M}$ phases in contrast to the G0/G1 phase [81]. This is in accordance with the increase in cellular $\mathrm{O}_{2}^{-}$levels observed during the $\mathrm{S}$ and $\mathrm{G} 2$ phases in normal cells [82]. Changes in MnSOD and ROS levels during cell cycle progression are more difficult to observe in transformed cells and tumor cells, which are continuously in proliferation and whose duration of cell cycle is greatly shortened. Even if MnSOD expression is low in noninvasive 
breast tumor cells with a high proliferation rate, no important changes in its level are observed during cell cycle progression, because the G1 phase is greatly shortened. A prolongation of $\mathrm{G} 1 / \mathrm{S}$ transition time has been observed, but not of G2/M transition time, in MnSOD-overexpressing mouse fibroblast cells, resulting in a decrease in cell growth in contrast to the wild-type fibroblasts [83]. In the same way, transfection of cDNA encoding MnSOD in the human estrogen-dependent and noninvasive breast cancer MCF-7 cell line greatly reduced cell growth [60].

\section{The link between MnSOD and proliferation of breast tumor cells}

The low expression of MnSOD in breast cancer cells intensifies the accumulation of $\mathrm{O}_{2}^{-}$- promoted mainly by a defect in oxidative phosphorylation in mitochondria and by overexpression of some subunits forming NADPH oxidase. The mitochondrial respiratory chain through oxidative phosphorylation is made up of five multiprotein complexes (I to IV and ATP synthase) embedded in the inner membrane. Only complexes I, II, and III generate $\mathrm{O}_{2}^{--}$. Some alterations in nuclear genes encoding proteins of these complexes have been shown in breast cancer cells. Particularly, the A10398G polymorphism, which results in the substitution of threonine for alanine within the NADH dehydrogenase subunit of complex I in the respiratory chain, has been associated with increased risk of breast cancer $[84,85]$. This polymorphism may lead to impaired respiratory function and so to increased $\mathrm{O}_{2}^{\bullet-}$ production. In addition, it has been observed in breast cancer cells and tumors that the defect in oxidative phosphorylation may be due to changes in gene expression associated with the complexes. Recently, a dramatically reduced level of complex I and III activities was measured in breast cancer cells and primary breast tumors resulting in an overexpression of a component of these complexes, the Rieske iron-sulfur protein [86,87].

The defect in mitochondrial function leads breast tumor cells to change toward aerobic glycolysis (Warburg effect) as an alternative source of ATP production, which is essential to maintaining the energy demand required for proliferation [88]. It has been suggested that this is particularly true during the early stages of breast tumorigenesis, when the normal integrity of mitochondria is not correctly maintained by a decrease in the MnSOD level [89]. In addition, an increment in the hypoxia zone in the breast tumor is often observed during exponential tumor growth, which increases mitochondrial $\mathrm{O}_{2}^{--}$production at the level of complex III, promoting activation of hypoxia-inducible factors (HIF) $[90,91]$. Some target genes of HIFs encode enzymes involved in the Warburg effect $[92,93]$. In addition to mitochondria, NADPH oxidase 1 (Nox1) activity is also a major source of endogenous $\mathrm{O}_{2}^{\bullet-}$ in cells. The Nox family of NADPH oxidases contains seven structurally related members that are homologous to Nox1, namely gp91, or Nox2. Until recently, Nox proteins were known as $\mathrm{O}_{2}^{--}$-producing enzymes that were traditionally thought to be involved in host defense. However, recent studies have shown that Nox's 1, 2, 3, and 5 are overexpressed in breast cancer cells and primary carcinomas and play roles in tumor cell signaling through $\mathrm{O}_{2}^{--}$production see for review [94]. In addition, it has been demonstrated that mitochondria cross talk with Nox proteins via $\mathrm{O}_{2}^{\bullet-}$ production, because inactivation of mitochondrial genes or inhibitors of oxidative phosphorylation leads to a downregulation of Nox protein expression $[86,95,96]$. In the case of ER-positive breast cancer cells, $\mathrm{O}_{2}^{\bullet-}$ may be generated by the redox cycling of catechol estrogens from their exposure to physiological concentrations of estrogens [97]. The role of estrogen-induced $\mathrm{O}_{2}^{\bullet-}$ has been extensively reviewed in the activation of signaling pathways that contribute to ER-positive breast tumor growth [5].

The superoxide anion radical overproduced in mitochondria, which is not dismutated sufficiently to $\mathrm{H}_{2} \mathrm{O}_{2}$ by the low MnSOD level, may diffuse across the mitochondrial membrane via the voltage-dependent anion channel pore, to be released into the cytosol [98]. Moreover, extracellular $\mathrm{O}_{2}^{--}$generated from Nox activity diffuses across the plasma membrane. Then, this ROS mediates the role of MnSOD in proliferation of breast cancer cells by affecting intracellular signaling pathways as well as the activity of some redox-sensitive transcription factors. The superoxide anion radical has been described to stimulate breast tumor cell proliferation by activating MAPK pathways such as extracellular signal-regulated kinase (ERK) and c-Jun N-terminal kinase, which are responsible for the activation of the transcription factor AP-1, which plays a key role in cell cycle progression [99]. It has been shown that $\mathrm{O}_{2}^{--}$production induced by hypoxic conditions in breast tumors may reduce breast cancer stem cell quiescence and promote their proliferation by activating stress-activated signaling pathways such as p38 MAPK [100]. The fact that several breast cancer cell lines express low MnSOD levels and high levels of $\mathrm{H}_{2} \mathrm{O}_{2}$-detoxifying enzymes (excepted GPX-1) suggests that $\mathrm{O}_{2}^{\bullet-}$ is mainly involved in cell proliferation [6]. All these data are depicted in Fig. 3.

\section{MnSOD as a mediator of DDB2 protein in cell proliferation}

We demonstrated recently that MnSOD could play a role as a mediator of the DDB2 protein in cell proliferation. DDB2, which controls negatively the expression of the SOD2 gene, has been described to play a role in the proliferation of nonmetastatic breast tumor cells expressing ER $\alpha$. The DDB2 gene is constitutively overexpressed in these tumor cells, and the corresponding protein stimulates their proliferation by favoring $\mathrm{G} 1 / \mathrm{S}$ transition entry and their progression through the $\mathrm{S}$ phase of the cell cycle. This is associated with an increase in the expression of S-phase markers of the cell cycle, such as cyclin E, proliferating cell nuclear antigen, and dihydrofolate reductase [70], but also a decrease in MnSOD levels. Indeed, the inhibition of cell proliferation observed after DDB2 knockdown in nonmetastatic breast tumor cells is restored when the increased MnSOD expression as a consequence is inhibited by specific antisense RNAs [68]. Also, we suggest that a better understanding of SOD2 gene regulation may explain the role of MnSOD in tumor cell proliferation.

\section{Role of MnSOD in angiogenic activity of breast tumor cells}

Tumoral angiogenesis is essential for the growth and spread of breast tumor cells. There are several different angiogenic growth factors associated with tumoral angiogenesis in breast cancer, but the major mediator is vascular endothelial growth factor (VEGF), a homodimeric heparin-binding glycoprotein whose gene is mainly targeted by HIF transcription factor [101,102]. This factor is activated by a reduced oxygen availability, which may be caused by a high rate of cell proliferation encountered in breast tumors [103]. VEGF production may be increased by synergy between ROS $\left(\mathrm{O}_{2}^{\bullet-}\right.$ and $\left.\mathrm{H}_{2} \mathrm{O}_{2}\right)$ and tumor hypoxia, causing blood vessel growth within the breast carcinoma microenvironment, which promotes not only tumor growth but also the risk of blood-borne metastasis and lymphatic dissemination.

During tumor growth, increments of hypoxia for low-MnSODexpressing breast tumor cells are accompanied by an increase in mitochondrial $\mathrm{O}_{2}^{--}$production at the level of complex III, responsible for stabilizing the HIF- $1 \alpha$ protein [90,91]. Indeed, a moderate overexpression of MnSOD in noninvasive MCF-7 cells lowers $\mathrm{O}_{2}^{-}$levels, which promotes the suppression of hypoxic accumulation of HIF- $1 \alpha$ protein at low levels of oxygen, resulting in a decrease in the secretion of VEGF [104].

Along with facilitating tumor growth, angiogenesis enables breast tumor cells to spread through the bloodstream to distant sites. Also high MnSOD activity in invasive and metastatic breast tumor cells induces angiogenesis by an increase in the level of $\mathrm{H}_{2} \mathrm{O}_{2}$ without a concomitant increase in the expression of $\mathrm{H}_{2} \mathrm{O}_{2}$-detoxifying enzymes [6]. $\mathrm{H}_{2} \mathrm{O}_{2}$ has been shown to stimulate blood vessel growth through 


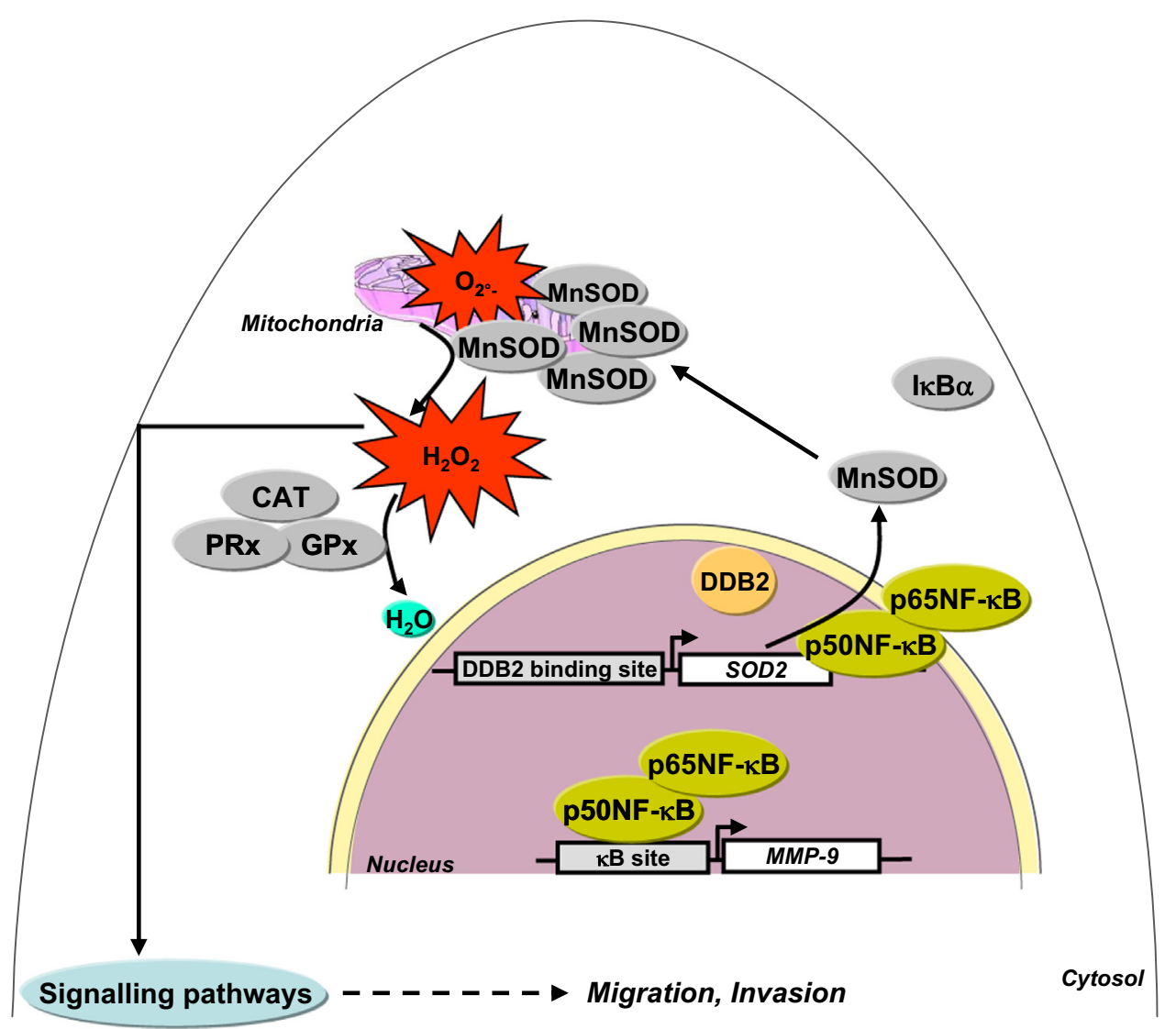

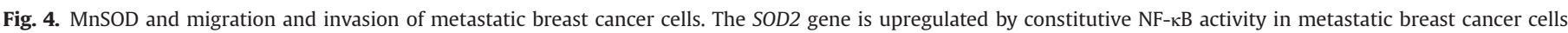

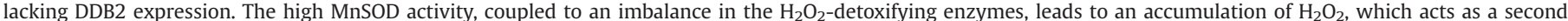
messenger promoting migration and invasion of tumor cells through activation of signaling pathways.

two distinct pathways converging on HIF- $1 \alpha . \mathrm{H}_{2} \mathrm{O}_{2}$ may promote directly accumulation of HIF- $1 \alpha$, which is prevented when mitochondrial $\mathrm{H}_{2} \mathrm{O}_{2}$-detoxifying enzymes are overexpressed in breast cancer cells with high MnSOD activity [104]. In addition, $\mathrm{H}_{2} \mathrm{O}_{2}$ may oxidize and inactivate the tumor suppressor phosphatase and tensin homolog deleted from chromosome 10 (PTEN), through disulfide bond formation between cysteine residues located in the catalytic domain, which promotes the activation of the protein kinase $\mathrm{B}$ (PKB)/Akt pathway and in turn the increase of VEGF expression induced by NF- $\kappa B \quad[105,106]$. This transcription factor is activated after phosphorylation of the p65 subunit by PKB/Akt and is able to induce HIF-1 $\alpha$ gene expression [107-109]. Another mechanism may explain how HIF-1 $\alpha$ accumulation would be mediated by MnSOD in breast cancer cells. This mechanism is based on the sensitivity of the prolyl-hydroxylases (PHDs) to $\mathrm{O}_{2}^{--}$or $\mathrm{H}_{2} \mathrm{O}_{2}$. In their oxidized form, the PHD family proteins are unable to hydroxylate proline residues of HIF- $1 \alpha$, which in turn cannot bind to the von Hippel-Lindau factor to be ubiquitinylated and then degraded by the $26 \mathrm{~S}$ proteasome [110].

Taken together, these observations suggest that MnSOD, by modulating $\mathrm{O}_{2}^{-}{ }^{-}$or $\mathrm{H}_{2} \mathrm{O}_{2}$ levels according to its expression in breast cancer cells, plays an important role in angiogenesis by regulating HIF-1 $\alpha$ accumulation.

\section{Role of MnSOD in metastatic properties of breast cancer cells}

The link between MnSOD and invasive abilities of breast cancer cells

High MnSOD expression, dependent on constitutive NF- $\kappa B$ activity and the lack of DDB2 and AP-2 $\alpha$ expression (Fig. 2B), is correlated with the invasive and the metastatic properties of breast cancer cells and is coupled to an imbalance in $\mathrm{H}_{2} \mathrm{O}_{2}$ detoxifying antioxidant enzyme expression (Fig. 4), thus promoting an accumulation of $\mathrm{H}_{2} \mathrm{O}_{2}$ in these aggressive cells [4,6]. Several studies report that the role of MnSOD in invasive properties of aggressive breast cancer cells is mediated by $\mathrm{H}_{2} \mathrm{O}_{2}$, because overexpression of catalase or addition of $\mathrm{H}_{2} \mathrm{O}_{2}$ scavengers reverses the effect of high MnSOD expression on the invasive phenotype [6,60]. In addition, administration of the polyphenol curcumin, which scavenges $\mathrm{H}_{2} \mathrm{O}_{2}$, to nude mice xenografted with human aggressive breast tumors reduces development of lung metastases [111,112].

High MnSOD expression is associated with a slower proliferation rate of invasive cancer cells, because the increased intracellular level of $\mathrm{H}_{2} \mathrm{O}_{2}$ alters the cellular redox environment, which influences progression through the cell cycle and may increase the mitochondrial potential through activation of mitochondrial $\mathrm{K}_{\mathrm{ATP}}$ channels [113-115].

\section{MnSOD and epithelial-mesenchymal transition of breast tumor cells}

In addition to regulating growth rate, MnSOD, by producing $\mathrm{H}_{2} \mathrm{O}_{2}$, may control mechanisms that are associated with the formation of breast tumor metastases (Fig. 5). For that, the epithelial breast tumor cells must acquire their migratory and invasive properties by undergoing a key cellular process termed epithelialmesenchymal transition (EMT). This process corresponds to, first, a decrease in cell/cell adhesion and cell adhesion to the basal lamina and, second, an increase in migratory and invasive potentials that favors breast cancer cells entering blood vessels [116].

The loss of adhesion of normal cells induces a type of apoptosis termed anoikis, which is essential for the prevention of dissemination of cells to inappropriate sites [117]. Also, resistance of 


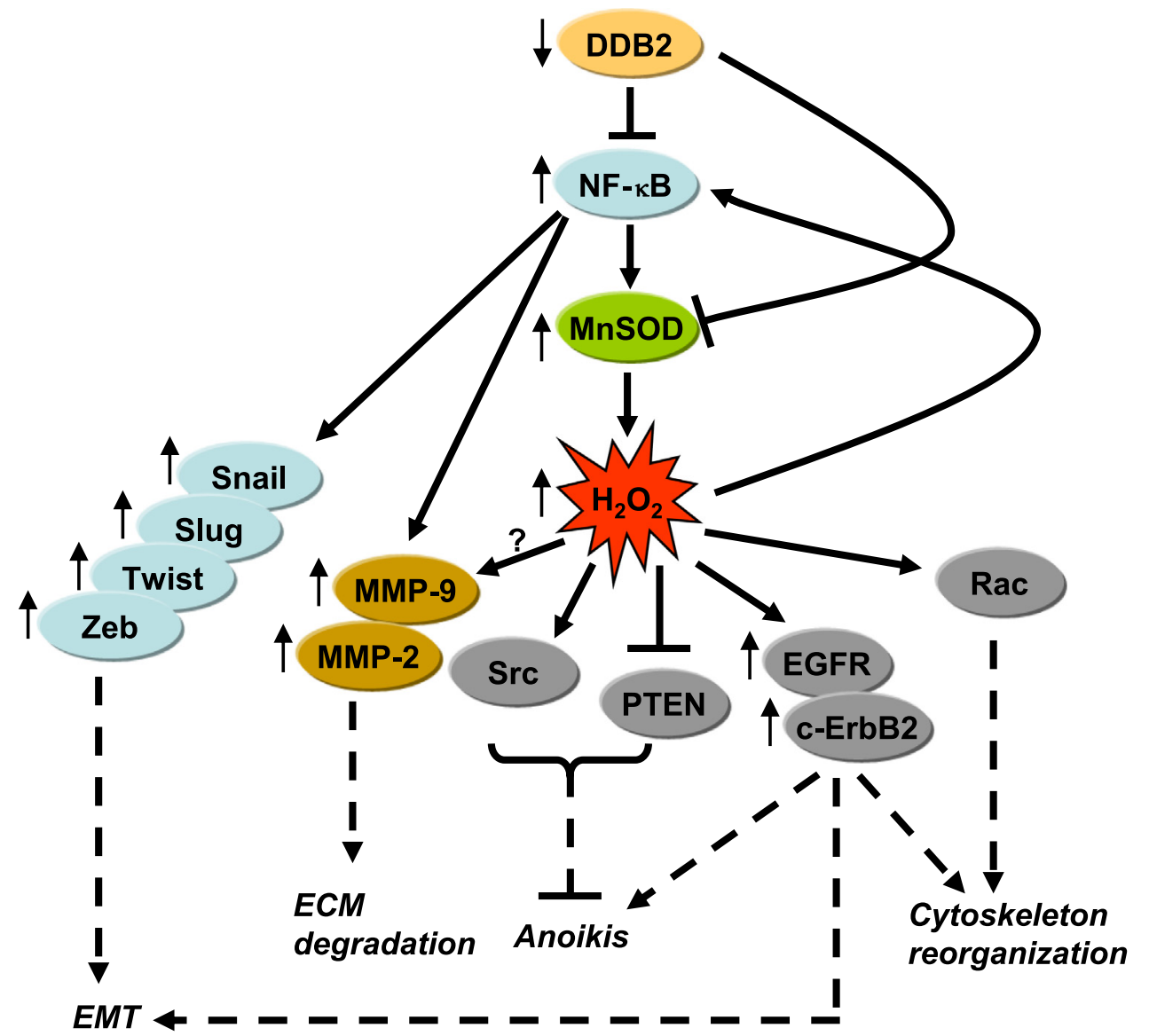

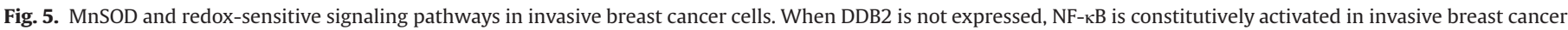

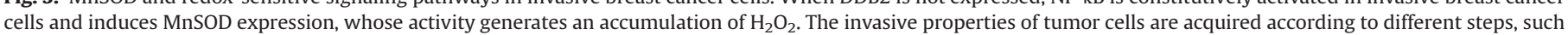

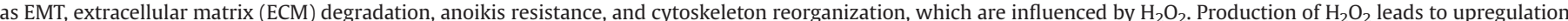

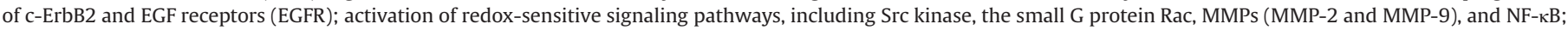

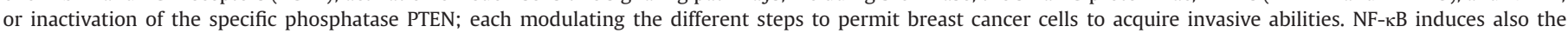
expression of transcription factors playing a central role in the EMT program.

breast cancer cells to anoikis is an important step during the metastatic process. A recent study reports that upregulation of MnSOD contributes to anoikis resistance by increasing high $\mathrm{H}_{2} \mathrm{O}_{2}$ levels, and MnSOD-depleted invasive breast MDA-MB435 tumor cells exhibit increased anoikis when detached [118]. It is known that this $\mathrm{H}_{2} \mathrm{O}_{2}$ released from MnSOD activity may activate the c-Src oncoprotein, as well as inactivating PTEN, and enhance expression of epithelial growth factor (EGF) and c-ErbB2 receptors, all leading to a sustained stimulation of prosurvival signals and anoikis resistance [119-121]. In addition, MnSOD-dependent $\mathrm{H}_{2} \mathrm{O}_{2}$ may be responsible for a redistribution of E-cadherin, a critical mediator in cell adhesion, and upregulation of some integrin members that promote dissemination of cancer cells [122].

MnSOD may also contribute to the genetic program of EMT by producing $\mathrm{H}_{2} \mathrm{O}_{2}$. This ROS is able to activate NF- $\mathrm{KB}$, which plays a central role in the genetic program of EMT, by inducing directly or indirectly the expression of a family of zinc finger transcription factors, including Snail, Slug, Twist, and Zeb1 and Zeb2 [123-125]. These actors are typical of EMT because they repress epithelial gene expression, as the best-studied cases, E-cadherin and $\gamma$-catenin, promote the loss of epithelial cell adhesion and polarity [116]. Hydrogen peroxide-activated NF- $\kappa B$ also induces EMT by inducing genes encoding mesenchymal markers, particularly vimentin, $\mathrm{N}$-cadherin, fibronectin, and matrix metalloprotease-9 (MMP-9), whose expression in breast cancer is correlated with advanced tumor grade [126-129]. The expression of typical EMT transcription factors can be also induced by $\mathrm{H}_{2} \mathrm{O}_{2}$-activated HIF- $1 \alpha$, which furthers angiogenesis and tumor cell dissemination [130].

Finally, it has also been shown that $\mathrm{H}_{2} \mathrm{O}_{2}$ may activate small $\mathrm{G}$ protein Rac-dependent signaling pathways, which are involved in the reorganization of the cytoskeleton, an important feature of EMT explaining the change of epithelial to mesenchymal morphology in tumor cells [122].

\section{MnSOD and the extracellular matrix degradation surrounding invasive breast tumor cells}

Subsequently, invasion and metastasis are facilitated by the acquired ability of aggressive tumor cells with a mesenchymal phenotype to degrade their surrounding extracellular matrix to permit them to enter the bloodstream. It has been shown that MnSOD may contribute to this ability by activating MMPs and inhibiting antiproteases. This effect is mediated by $\mathrm{H}_{2} \mathrm{O}_{2}$, which activates pro-MMPs directly or induces their gene expression through activation of redox-sensitive transcription factors. It has been demonstrated for the first time in fibrosarcoma cells that MnSOD-dependent $\mathrm{H}_{2} \mathrm{O}_{2}$ production contributes to the activation of the ERK1/2 signaling pathway and subsequent activation of the redox-sensitive AP-1 transcription factor, leading to a transcriptional increase in interstitial collagenase MMP-1 expression [131,132]. This $\mathrm{H}_{2} \mathrm{O}_{2}$-dependent activation of MMP-1 promotes the loss of focal 
adhesions as well as the development of lung metastases in immunodeficient mice xenografted with fibrosarcoma cells [133].

In the case of breast cancer, MMP-2 and - 9 are gelatinases that play a major role in invasive and metastatic properties of cancer cells. High levels of MMP-2 and -9 correlate with poor prognosis in breast cancer patients and active MMP-2 and -9 are detected more frequently in malignant than in benign breast tumors [126]. MMP-2 and -9 expression is regulated by AP-1 and NF- $\kappa \mathrm{B}$, respectively, which can be activated by $\mathrm{H}_{2} \mathrm{O}_{2}$. In addition, $\mathrm{H}_{2} \mathrm{O}_{2}$ can activate MMP-2 and -9 directly, by reacting with thiol groups in the protease catalytic domain. Like all MMPs, they are secreted in a latent zymogen form in which the cleavage of the prodomain is ROS dependent $[134,135]$. When MnSOD is overexpressed in noninvasive breast cancer MCF-7 cells after transfection with the corresponding cDNA, cell proliferation is reduced, whereas cell invasiveness is enhanced by activation of MMP-2. This effect of MnSOD is abolished after overexpression of catalase or addition of $\mathrm{H}_{2} \mathrm{O}_{2}$ scavengers [136]. In the same way, MnSOD gene induction by progestin, occurring through the progesterone receptor, stimulates the migration and invasion of nonmetastatic breast cancer MCF-7 and T47D cells [137]. Inversely, we demonstrated that $\mathrm{H}_{2} \mathrm{O}_{2}$ from MnSOD activity is overproduced and plays a role in the invasive ability of estrogen-independent and metastatic breast cancer cells, by activating particularly MMP-9. Also, inhibition of MnSOD by specific antisense RNAs decreased migration and invasion of MDA-MB231 cells by promoting a decrease in $\mathrm{H}_{2} \mathrm{O}_{2}$ levels and in consequence a decrease in activation of secreted MMP-9 [6]. The same results were obtained by using a $\mathrm{H}_{2} \mathrm{O}_{2}$ scavenger such as curcumin, through inhibition of NF- $\mathrm{KB}$ activity $[111,138]$.

It is known that the tumor microenvironment influences tumor progression and angiogenesis. Also, we can suppose that $\mathrm{H}_{2} \mathrm{O}_{2}$ produced in breast cancer cells is in part released into the tumor microenvironment and activates cancer-associated fibroblasts. These factors contribute to breast tumor progression by secreting MMPs, VEGF, and other soluble factors that promote cell motility, angiogenesis, and metastasis see for review 3, [139].

\section{Conclusions and clinical perspectives}

The role of MnSOD in cancer, including breast cancer, has been greatly studied and is associated with profound alterations in SOD2 gene expression by various molecular mechanisms. This review summarized main findings that bring a new understanding of breast tumor growth and how breast cancer cells progress toward an invasive phenotype according to MnSOD levels. Distinct SOD2 gene expression between normal mammary epithelium and early stages of breast tumors leads us to postulate that MnSOD represents a good candidate as a diagnosis marker in breast cancer, as already suggested in malignant pleural mesothelioma [140]. Distinct SOD2 gene expression between early and advanced stages in breast cancer lead us to postulate that MnSOD also represents a good candidate as a prognostic and/or a predicting marker for breast tumor progression toward the metastatic status. Whereas downregulation of MnSOD may be considered an advantage for proliferation of nonmetastatic breast cancer cells, the upregulation of MnSOD may represent one of the mechanisms by which metastatic breast cancer cells increase their invasive capacity by boosting the intracellular concentration of $\mathrm{H}_{2} \mathrm{O}_{2}$ (Fig. 4). In this case, it may be suggested that upregulation of MnSOD is associated with a poor prognosis in advanced breast cancer because of an increased risk of metastasis and patient mortality. This potential clinical interest of MnSOD is relevant actually because of the lack of sufficiently reliable predictive and/or prognostic biological markers for breast tumor progression toward a metastatic phenotype. However, before we are able to consider the clinical significance of MnSOD as a predictive and/or prognosis biomarker, it will need evaluation of its expression level in primary tumors and lymph nodes as well as metastases from a large cohort of patients with breast cancer and a correlation of the data with clinical parameters such as relapse-free, as well as overall and distant metastasis-free, survival of patients. In addition, a better understanding of the molecular mechanisms explaining the distinct basal expression of the SOD2 gene between nonmetastatic and metastatic cancer cells, as well as the involvement of MnSOD in tumor growth, may contribute to predicting metastatic progression in breast cancers. Also, it will be interesting to evaluate the concomitant clinical interest of MnSOD and the factors influencing its expression as well as the proteins involved in metastatic processes such as EMT. Some of these proteins not only present an important clinical interest, but also constitute potential targets for future development of new anticancer therapies.

\section{Acknowledgments}

The authors are grateful to the following financial supporters: the Ligue contre le Cancer (Comités Meuse and Vosges), the University of Lorraine, and Région Lorraine. C. Barbieux and R. Klotz have a fellowship from the French Research Ministry. The authors are also grateful to Professor S.N. Thornton for critical reading of the manuscript.

\section{References}

[1] Mitrunen, K.; Hirvonen, A. Molecular epidemiology of sporadic breast cancer: the role of polymorphic genes involved in oestrogen biosynthesis and metabolism. Mutat. Res. 544:9-41; 2003.

[2] Vera-Ramirez, L.; Sanchez-Rovira, P.; Ramirez-Tortosa, M. C.; RamirezTortosa, C. L.; Granados-Principal, S.; Lorente, J. A.; Quiles, J. L. Free radicals in breast carcinogenesis, breast cancer progression and cancer stem cells: biological bases to develop oxidative-based therapies. Crit. Rev. Oncol. Hematol. 80:347-368; 2011.

[3] Sosa, V.; Moliné, T.; Somoza, R.; Paciucci, R.; Kondoh, H.; Lleonart, M. E. Oxidative stress and cancer: an overview. Ageing Res. Rev. 12:376-390; 2013.

[4] Ridnour, L. A.; Oberley, T. D.; Oberley, L. W. Tumor suppressive effects of MnSOD overexpression may involve imbalance in peroxide generation versus peroxide removal. Antioxid. Redox Signaling 6:501-512; 2004.

[5] Okoh, V.; Deoraj, A.; Roy, D. Estrogen-induced reactive oxygen speciesmediated signalings contribute to breast cancer. Biochim. Biophys. Acta 1815:115-133; 2011.

[6] Kattan, Z.; Minig, V.; Leroy, P.; Dauça, M.; Becuwe, P. Role of manganese superoxide dismutase on growth and invasive properties of human estrogenindependent breast cancer cells. Breast Cancer Res. Treat. 108:203-215; 2008.

[7] Nishida, S.; Akai, F.; Iwasaki, H.; Hosokawa, K.; Kusunoki, T.; Suzuki, K.; Taniguchi, N.; Hashimoto, S.; Tamura, T. T. Manganese superoxide dismutase content and localization in human thyroid tumours. J. Pathol. 169:341-345 1993.

[8] Cobbs, C. S.; Levi, D. S.; Aldape, K.; Israel, M. A. Manganese superoxide dismutase expression in human central nervous system tumors. Cancer Res. 56:3192-3195; 1996.

[9] Landriscina, M.; Remiddi, F; Ria, F.; Palazzotti, B;: De Leo, M. E; Iacoangeli, M. Rosselli, R.; Scerrati, M.; Galeotti, T. The level of MnSOD is directly correlated with grade of brain tumours of neuroepithelial origin. Br. J. Cancer 74:1877-1885; 1996.

[10] Kahlos, K.; Anttila, S.; Asikainen, T.; Kinnula, K.; Raivio, K. O.; Mattson, K; Linnainmaa, K.; Kinnula, V. L. Manganese superoxide dismutase in healthy human pleural mesothelium and in malignant pleural mesothelioma. Am. J. Respir. Cell Mol. Biol. 18:570-580; 1998.

[11] Janssen, A. M.; Bosman, C. B.; van Duijn, W.; Oostendorp-van de Ruit, M. M.; Kubben, F. J.; Griffioen, G.; Lamers, C. B.; van Krieken, J. H.; van de Velde, C. J.; Verspaget, H. W. Superoxide dismutases in gastric and esophageal cancer and the prognostic impact in gastric cancer. Clin. Cancer Res. 6:3183-3192; 2000.

[12] Malafa, M.; Margenthaler, J.; Webb, B.; Neitzel, L.; Christophersen, M. MnSOD expression is increased in metastatic gastric cancer. J. Surg. Res. 88:130-134; 2000.

[13] Hu, Y.; Rosen, D. G.; Zhou, Y.; Feng, L.; Yang, G.; Liu, J.; Huang, P. Mitochondrial manganese-superoxide dismutase expression in ovarian cancer: role in cell proliferation and response to oxidative stress. J. Biol. Chem. 280:39485-39492; 2005.

[14] Weisiger, R. A.; Fridovich, I. Mitochondrial superoxide dismutase: site of synthesis and intramitochondrial localization. J. Biol. Chem. 248:4793-4796; 1973. 
[15] Okado-Matsumoto, A.; Fridovich, I. Subcellular distribution of superoxide dismutases (SOD) in rat liver: Cu,Zn-SOD in mitochondria. J. Biol. Chem. 276:38388-38393; 2001

[16] Lebovitz, R. M.; Zhang, H.; Vogel, H.; Cartwright Jr J.; Dionne, L.; Lu, N.; Huang, S.; Matzuk, M. M. Neurodegeneration, myocardial injury, and perinatal death in mitochondrial superoxide dismutase-deficient mice. Proc. Natl. Acad. Sci. USA 93:9782-9787; 1996.

[17] Clair St D. K.; Wan, X. S.; Oberley, T. D.; Muse, K. E.; Clair St W. H. Suppression of radiation-induced neoplastic transformation by overexpression of mitochondrial superoxide dismutase. Mol. Carcinog. 6:238-242; 1992.

[18] Kiningham, K. K.; Oberley, T. D.; Lin, S.; Mattingly, C. A.; Clair St D. K. Overexpression of manganese superoxide dismutase protects against mitochondrial-initiated poly(ADP-ribose) polymerase-mediated cell death. FASEB J. 13:1601-1610; 1999.

[19] Bica, C. G.; de Moura da Silva, L. L.; Toscani, N. V.; da Cruz, I. B.; Sá, G.; Graudenz, M. S.; Zettler, C. G. MnSOD gene polymorphism association with steroid-dependent cancer. Pathol. Oncol. Res. 15:19-24; 2009.

[20] Church, S. L.; Grant, J. W.; Meese, E. U.; Trent, J. M. Sublocalization of the gene encoding manganese superoxide dismutase (MnSOD/SOD2) to 6q25 by fluorescence in situ hybridization and somatic cell hybrid mapping. Genomics 14:823-825; 1992.

[21] Dhar, S. K.; Clair St D. K. Manganese superoxide dismutase regulation and cancer. Free Radic. Biol. Med. 52:2209-2222; 2012.

[22] Wan, X. S.; Devalaraja, M. N.; Clair St D. K. Molecular structure and organization of the human manganese superoxide dismutase gene. DNA Cell Biol 13:1127-1136; 1994

[23] Maehara, K.; Hasegawa, T.; Xiao, H.; Takeuchi, A.; Abe, R.; Isobe, K. Cooperative interaction of NF-kappaB and C/EBP binding sites is necessary for manganese superoxide dismutase gene transcription mediated by lipopolysaccharide and interferon-gamma. FEBS Lett. 449:115-119; 1999.

[24] Xu, Y.; Kiningham, K. K.; Devalaraja, M. N.; Yeh, C. C.; Majima, H.; Kasarskis, E. J.; Clair St D. K. An intronic NF-kappaB element is essential for induction of the human manganese superoxide dismutase gene by tumor necrosis factoralpha and interleukin-1beta. DNA Cell Biol 18:709-722; 1999.

[25] Oiu, X.; Aiken, K. J.; Chokas, A. L.: Beachy, D. E.; Nick, H. S. Distinct function of CCAAT enhancer-binding protein isoforms in the regulation of manganese superoxide dismutase during interleukin-1beta stimulation. J. Biol. Chem 283:25774-25785; 2008

[26] Cyr, A. R.; Hitchler, M. J.; Domann, F. E. Regulation of SOD2 in cancer by histone modifications and $\mathrm{CpG}$ methylation: closing the loop between redox biology and epigenetics. Antioxid. Redox Signaling 18:1946-1955; 2013.

[27] Kim, H. P.; Roe, J. H.; Chock, P. B.; Yim, M. B. Transcriptional activation of the human manganese superoxide dismutase gene mediated by tetradecanoylphorbol acetate. J. Biol. Chem. 274:37455-37460; 1999.

[28] Bianchi, A.; Becuwe, P.; Franck, P.; Dauça, M. Induction of MnSOD gene by arachidonic acid is mediated by reactive oxygen species and p38 MAPK signaling pathway in human HepG2 hepatoma cells. Free Radic. Biol. Med. 32:1132-1142; 2002

[29] Zhao, Y.; Clair St D. K. Detection of the content and activity of the transcription factor AP-1 in a multistage skin carcinogenesis model. Methods Mol. Biol. 218:177-184; 2003.

[30] Kops, G. J.; Dansen, T. B.; Polderman, P. E.; Saarloos, I.; Wirtz, K. W.; Coffer, P. J.; Huang, T. T.; Bos, J. L.; Medema, R. H.; Burgering, B. M. Forkhead transcription factor FOXO3a protects quiescent cells from oxidative stress. Nature 419:316-321; 2002

[31] Porntadavity, S.; Xu, Y.; Kiningham, K.; Rangnekar, V. M.; Prachayasittikul, V.; Clair St D. K. TPA-activated transcription of the human MnSOD gene: role of transcription factors Sp-1 and Egr-1. DNA Cell Biol 20:473-481; 2001.

[32] Xu, Y.; Porntadavity, S.; Clair St D. K. Transcriptional regulation of the human manganese superoxide dismutase gene: the role of specificity protein 1 (Sp1) and activating protein-2 (AP-2). Biochem. J. 362:401-412; 2002.

[33] Zhu, C. H.; Huang, Y.; Oberley, L. W.; Domann, F. E. A family of AP-2 proteins down-regulate manganese superoxide dismutase expression. J. Biol. Chem. 276:14407-14413; 2001.

[34] Maehara, K.; Oh-Hashi, K.; Isobe, K. I. Early growth-responsive-1-dependent manganese superoxide dismutase gene transcription mediated by plateletderived growth factor. FASEB J. 15:2025-2026; 2001.

[35] Dhar, S. K.; Lynn, B. C.; Daosukho, C.; Clair St D. K. Identification of nucleophosmin as an NF-kappaB co-activator for the induction of the human SOD2 gene. J. Biol. Chem. 279:28209-28219; 2004.

[36] Xu, Y. Fang, F: Dhar, S. K. Clair St W. H.; Kasarskis, E. J.; Clair St D. K. The role of a single-stranded nucleotide loop in transcriptional regulation of the human sod2 gene. J. Biol. Chem. 282:15981-15994; 2007.

[37] Kwak, M. K.; Itoh, K.: Yamamoto, M.; Sutter, T. R.; Kensler, T. W. Role of transcription factor Nrf2 in the induction of hepatic phase 2 and antioxidative enzymes in vivo by the cancer chemoprotective agent, $3 \mathrm{H}-1$, 2-dimethiole-3-thione. Mol. Med. 7:135-145; 2001.

[38] Hussain, S. P.; Amstad, P.; He, P.; Robles, A.; Lupold, S.; Kaneko, I.; Ichimiya, M.; Sengupta, S.; Mechanic, L.; Okamura, S.; Hofseth, L. J.; Moake, M. Nagashima, M.; Forrester, K. S.; Harris, C. C. p53-induced up-regulation of MnSOD and GPx but not catalase increases oxidative stress and apoptosis. Cancer Res. 64:2350-2356; 2004

[39] Huang, Y.; He, T.; Domann, F. E. Decreased expression of manganese superoxide dismutase in transformed cells is associated with increased cytosine methylation of the SOD2 gene. DNA Cell Biol 18:643-652; 1999.
[40] Maehara, K.; Uekawa, N.; Isobe, K. Effects of histone acetylation on transcriptional regulation of manganese superoxide dismutase gene. Biochem. Biophys. Res. Commun. 295:187-192; 2002.

[41] Xu, Y.; Krishnan, A.; Wan, X. S.; Majima, H.; Yeh, C. C.; Ludewig, G.; Kasarskis, E. J.; Clair St D. K. Mutations in the promoter reveal a cause for the reduced expression of the human manganese superoxide dismutase gene in cancer cells. Oncogene 18:93-102; 1999.

[42] Sutton, A.; Khoury, H.; Prip-Buus, C.; Cepanec, C.; Pessayre, D.; Degoul, F. The Ala16Val genetic dimorphism modulates the import of human manganese superoxide dismutase into rat liver mitochondria. Pharmacogenetics 13:145-157; 2003.

[43] McAtee, B. L.; Yager, J. D. Manganese superoxide dismutase: effect of the ala16val polymorphism on protein, activity, and mRNA levels in human breast cancer cell lines and stably transfected mouse embryonic fibroblasts. Mol. Cell. Biochem. 335:107-118; 2010.

[44] Bergman, M.; Ahnström, M.; Palmebäck Wegman, P.; Wingren, S. Polymorphism in the manganese superoxide dismutase (MnSOD) gene and risk of breast cancer in young women. J. Cancer Res. Clin. Oncol. 131:439-444; 2005.

[45] Millikan, R. C.; Player, J.; de Cotret, A. R.; Moorman, P.; Pittman, G. Vannappagari, V.; Tse, C. K.; Keku, T. Manganese superoxide dismutase Ala-9Val polymorphism and risk of breast cancer in a population-based case-control study of African Americans and whites. Breast Cancer Res. 6: R264-274; 2004.

[46] Wang, S.; Wang, F.; Shi, X.; Dai, J.; Peng, Y.; Guo, X.; Wang, X.; Shen, H.; Hu, Z. Association between manganese superoxide dismutase (MnSOD) Val-9Ala polymorphism and cancer risk-a meta-analysis. Eur. J Cancer 45:2874-2881; 2009.

[47] Cox, D. G.; Tamimi, R. M.; Hunter, D. J. Gene $\times$ gene interaction between MnSOD and GPX-1 and breast cancer risk: a nested case-control study. BMC Cancer 6:217; 2006.

[48] Brigelius-Flohé, R.; Maiorino, M. Glutathione peroxidases. Biochim. Biophys. Acta 1830:3289-3303; 2013.

[49] Cox, D. G.; Hankinson, S. E.; Kraft, P.; Hunter, D. J. No association between GPX1 Pro198Leu and breast cancer risk. Cancer Epidemiol. Biomarkers Prev 13:1821-1822; 2004

[50] Hu, J.; Zhou, G. W.; Wang, N.; Wang, Y. J. GPX1 Pro198Leu polymorphism and breast cancer risk: a meta-analysis. Breast Cancer Res. Treat. 124:425-431; 2010.

[51] Oestergaard, M. Z.; Tyrer, J.; Cebrian, A.; Shah, M.; Dunning, A. M.; Ponder, B. A.; Easton, D. F.; Pharoah, P. D. Interactions between genes involved in the antioxidant defence system and breast cancer risk. Br. J. Cancer 95:525-531; 2006.

[52] Kocabas, N. A.; Sardas, S.; Cholerton, S.; Daly, A. K.; Elhan, A. H.; Karakaya, A. E. Genetic polymorphism of manganese superoxide dismutase (MnSOD) and breast cancer susceptibility. Cell Biochem. Funct. 23:73-76; 2005.

[53] Slanger, T. E.; Chang-Claude, J.; Wang-Gohrke, S. Manganese superoxide dismutase Ala-9Val polymorphism, environmental modifiers, and risk of breast cancer in a German population. Cancer Causes Control 17:1025-1031; 2006.

[54] Mitrunen, K.; Sillanpää, P.; Kataja, V.: Eskelinen, M.; Kosma, V. M.; Benhamou, S.; Uusitupa, M.; Hirvonen, A. Association between manganese superoxide dismutase (MnSOD) gene polymorphism and breast cancer risk. Carcinogenesis 22:827-829; 2001.

[55] Egan, K. M.; Thompson, P. A.; Titus-Ernstoff, L.; Moore, J. H.; Ambrosone, C. B. MnSOD polymorphism and breast cancer in a population-based case-control study. Cancer Lett. 199:27-33; 2003.

[56] Gaudet, M. M.; Gammon, M. D.: Santella, R. M.: Britton, J. A.; Teitelbaum, S. L.; Eng, S. M.; Terry, M. B.; Bensen, J. T.; Schroeder, J.; Olshan, A. F.; Neugut, A. I.; Ambrosone, C. B. MnSOD Val-9Ala genotype, pro- and anti-oxidant environmental modifiers, and breast cancer among women on Long Island, New York. Cancer Causes Control 16:1225-1234; 2005.

[57] Seibold, P.; Hein, R.; Schmezer, P.; Hall, P.; Liu, J.; Dahmen, N.; Flesch-Janys, D.; Popanda, O.; Chang-Claude, J. Polymorphisms in oxidative stress-related genes and postmenopausal breast cancer risk. Int. J. Cancer 129:1467-1476; 2011.

[58] Bica, C. G.; da Silva, L. L.; Toscani, N. V.; Zettler, C. G.; Gottlieb, M. G.; Alexandre, C. O.: Graudenz, M. S.; Mânica da Cruz, I. B. Polymorphism (ALA16VAL) correlates with regional lymph node status in breast cancer. Cancer Genet. Cytogenet. 196:153-158; 2010.

[59] Martin, R. C.; Ahn, J.; Nowell, S. A.; Hein, D. W.; Doll, M. A.; Martini, B. D. Ambrosone, C. B. Association between manganese superoxide dismutase promoter gene polymorphism and breast cancer survival. Breast Cancer Res. 8:R45; 2006.

[60] Li, J. J.; Oberley, L. W.; Clair St D. K.; Ridnour, L. A.; Oberley, T. D. Phenotypic changes induced in human breast cancer cells by overexpression of manganese-containing superoxide dismutase. Oncogene 10:1989-2000; 1995.

[61] Tsanou, E.; Ioachim, E.; Briasoulis, E.; Damala, K.; Charchanti, A.; Karavasilis, V.; Pavlidis, N.; Agnantis, N. J. Immunohistochemical expression of superoxide dismutase (MnSOD) anti-oxidant enzyme in invasive breast carcinoma. Histol. Histopathol. 19:807-813; 2004.

[62] Soini, Y.; Vakkala, M.; Kahlos, K.; Pääkkö, P.; Kinnula, V. MnSOD expression is less frequent in tumour cells of invasive breast carcinomas than in in situ carcinomas or non-neoplastic breast epithelial cells. J. Pathol. 195:156-162; 2001. 
[63] Toh, Y.; Kuninaka, S.; Oshiro, T.; Ikeda, Y.; Nakashima, H.; Baba, H.; Kohnoe, S.; Okamura, T.; Mori, M.; Sugimachi, K. Overexpression of manganese superoxide dismutase mRNA may correlate with aggressiveness in gastric and colorectal adenocarcinomas. Int. J. Oncol. 17:107-112; 2000.

[64] Kahlos, K.; Soini, Y.; Pääkkö, P.; Säily, M.; Linnainmaa, K.; Kinnula, V. L. Proliferation, apoptosis, and manganese superoxide dismutase in malignant mesothelioma. Int. J. Cancer 88:37-43; 2000.

[65] Venkataraman, S.; Jiang, X.; Weydert, C.; Zhang, Y.; Zhang, H. J.; Goswami, P. C.; Ritchie, J. M.; Oberley, L. W.; Buettner, G. R. Manganese superoxide dismutase overexpression inhibits the growth of androgen-independent prostate cancer cells. Oncogene 24:77-89; 2005

[66] Hitchler, M. J.; Wikainapakul, K.; Yu, L.; Powers, K.; Attatippaholkun, W.; Domann, F. E. Epigenetic regulation of manganese superoxide dismutase expression in human breast cancer cells. Epigenetics 1:163-171; 2006.

[67] Hitchler, M. J.; Oberley, L. W.; Domann, F. E. Epigenetic silencing of SOD2 by histone modifications in human breast cancer cells. Free Radic. Biol. Med. 45:1573-1580; 2008.

[68] Minig, V.; Kattan, Z.; van Beeumen, J.; Brunner, E.; Becuwe, P. Identification of DDB2 protein as a transcriptional regulator of constitutive SOD2 gene expression in human breast cancer cells. J. Biol. Chem. 284:14165-14176; 2009.

[69] Douglas, D. B.; Akiyama, Y.; Carraway, H.; Belinsky, S. A.; Esteller, M.; Gabrielson, E.: Weitzman, S.; Williams, T.; Herman, J. G.; Baylin, S. B. Hypermethylation of a small CpGuanine-rich region correlates with loss of activator protein-2alpha expression during progression of breast cancer. Cancer Res. 64:1611-1620; 2004.

[70] Kattan, Z.; Marchal, S.; Brunner, E.; Ramacci, C.; Leroux, A.; Merlin, J. L.; Domenjoud, L.; Dauça, M.; Becuwe, P. Damaged DNA binding protein 2 plays a role in breast cancer cell growth. PLoS One 3:e2002; 2008.

[71] Keeney, S.; Chang, G. J.; Linn, S. Characterization of a human DNA damage binding protein implicated in xeroderma pigmentosum E. J. Biol. Chem. 268:21293-21300; 1993.

[72] Rapic Otrin, V.; Mc Lenigan, M.; Takao, M.; Levine, A. S.; Protic, M. Translocation of a UV-damaged DNA binding protein into a tight association after treatment of mammalian cells with UV light. J. Cell Sci. 110:1159-1168; 1997.

[73] Itoh, T. Xeroderma pigmentosum group E and DDB2. a smaller subunit of damage-specific DNA binding protein: proposed classification of xeroderma pigmentosum, Cockayne syndrome, and ultraviolet-sensitive syndrome. J. Dermatol. Sci. 41:87-96; 2006.

[74] Ennen, M.; Klotz, R.; Touche, N.; Pinel, S.; Barbieux, C.; Besancenot, V.; Brunner, E.; Thiebaut, D.; Jung, A. C.; Ledrappier, S.; Domenjoud, L.; Abecassis, J.; Plénat, F.; Grandemange, S.; Becuwe, P. DDB2: a novel regulator of NF-KB and breast tumor invasion. Cancer Res. 73:5040-5052; 2013.

[75] Luijsterburg, M. S.; Lindh, M.; Acs, K.; Vrouwe, M. G.; Pines, A.; van Attikum, H.; Mullenders, L. H.; Dantuma, N. P. DDB2 promotes chromatin decondensation at UV-induced DNA damage. J. Cell Biol. 197:267-281; 2012.

[76] Ennen, M.; Minig, V.; Grandemange, S.; Touche, N.; Merlin, J. L.; Besancenot, V.; Brunner, E.; Domenjoud, L.; Becuwe, P. Regulation of the high basal expression of the manganese superoxide dismutase gene in aggressive breast cancer cells. Free Radic. Biol. Med. 50:1771-1779; 2011.

[77] Nakshatri, H.; Bhat-Nakshatri, P.; Martin, D. A.; Goulet Jr R. J.; Sledge Jr. G. W. Constitutive activation of NF-kappaB during progression of breast cancer to hormone-independent growth. Mol. Cell. Biol. 17:3629-3639; 1997.

[78] Romieu-Mourez, R.; Landesman-Bollag, E.; Seldin, D. C.; Traish, A. M.; Mercurio, F.; Sonenshein, G. E. Roles of IKK kinases and protein kinase CK2 in activation of nuclear factor-kappaB in breast cancer. Cancer Res. 61:3810-3818; 2001.

[79] Yamamoto, M.; Ito, T.; Shimizu, T.; Ishida, T.; Semba, K.; Watanabe, S.; Yamaguchi, N.; Inoue, J. Epigenetic alteration of the NF-KB-inducing kinase (NIK) gene is involved in enhanced NIK expression in basal-like breast cancer. Cancer Sci. 101:2391-2397; 2010.

[80] Pianetti, S.; Arsura, M.; Romieu-Mourez, R.; Coffey, R. J.; Sonenshein, G. E. Her-2/neu overexpression induces NF-kappaB via a PI3-kinase/Akt pathway involving calpain-mediated degradation of IkappaB-alpha that can be inhibited by the tumor suppressor PTEN. Oncogene 20:1287-1299; 2001.

[81] Chaudhuri, L.; Nicholson, A. M.; Kalen, A. L.; Goswami, P. C. Preferential selection of MnSOD transcripts in proliferating normal and cancer cells. Oncogene 31:1207-1216; 2012.

[82] Sarsour, E. H.; Kalen, A. L.; Xiao, Z.; Veenstra, T. D.; Chaudhuri, L.; Venkataraman, S.; Reigan, P.; Buettner, G. R.; Goswami, P. C. Manganese superoxide dismutase regulates a metabolic switch during the mammalian cell cycle. Cancer Res. 72:3807-3816; 2012.

[83] Kim, A.; Zhong, W.; Oberley, T. D. Reversible modulation of cell cycle kinetics in $\mathrm{NIH} / 3 \mathrm{~T} 3$ mouse fibroblasts by inducible overexpression of mitochondrial manganese superoxide dismutase. Antioxid. Redox Signaling 6:489-500; 2004.

[84] Canter, J. A.; Kallianpur, A. R.; Parl, F. F.; Millikan, R. C. Mitochondrial DNA G10398A polymorphism and invasive breast cancer in African-American women. Cancer Res. 5:8028-8033; 2005.

[85] Setiawan, V. W.; Chu, L. H.; John, E. M.; Ding, Y. C.; Ingles, S. A.; Bernstein, L. Press, M. F.; Ursin, G.; Haiman, C. A.; Neuhausen, S. L. Mitochondrial DNA G10398A variant is not associated with breast cancer in African-American women. Cancer Genet. Cytogenet. 181:16-19; 2008.

[86] Owens, K. M.; Kulawiec, M.; Desouki, M. M.; Vanniarajan, A.; Singh, K. K. Impaired OXPHOS complex III in breast cancer. PLoS One 6:e23846; 2011.
[87] Sastre-Serra, J.; Nadal-Serrano, M.; Pons, D. G.; Valle, A.; Garau, I.; GarcíaBonafé, M.; Oliver, J.; Roca, P. The oxidative stress in breast tumors of postmenopausal women is ER $\alpha / E R \beta$ ratio dependent. Free Radic. Biol. Med. 61:11-17; 2013.

[88] Vander Heiden, M. G.; Cantley, L. C.; Thompson, C. B. Understanding the Warburg effect: the metabolic requirements of cell proliferation. Science 324:1029-1033; 2009.

[89] Robey, I. F.; Stephen, R. M.; Brown, K. S.; Baggett, B. K.; Gatenby, R. A.; Gillies R. J. Regulation of the Warburg effect in early-passage breast cancer cells. Neoplasia 10:745-756; 2008.

[90] Chandel, N. S.; McClintock, D. S.; Feliciano, C. E.; Wood, T. M.; Melendez, J. A.; Rodriguez, A. M.; Schumacker, P. T. Reactive oxygen species generated at mitochondrial complex III stabilize hypoxia-inducible factor-1alpha during hypoxia: a mechanism of $\mathrm{O}_{2}$ sensing. J. Biol. Chem. 275:25130-25138; 2000.

[91] Kaewpila, S.; Venkataraman, S.; Buettner, G. R.; Oberley, L. W. Manganese superoxide dismutase modulates hypoxia-inducible factor- 1 alpha induction via superoxide. Cancer Res. 68:2781-2788; 2008.

[92] Lu, H.; Forbes, R. A.; Verma, A. Hypoxia-inducible factor 1 activation by aerobic glycolysis implicates the Warburg effect in carcinogenesis. J. Biol. Chem. 277:23111-23115; 2002.

[93] Robey, I. F.; Lien, A. D.; Welsh, S. J.; Baggett, B. K.; Gillies, R. J. Hypoxiainducible factor-1alpha and the glycolytic phenotype in tumors. Neoplasia 7:324-330; 2005.

[94] Weyemi, U.; Redon, C. E.; Parekh, P. R.; Dupuy, C.; Bonner, W. M. NADPH oxidases NOXs and DUOXs as putative targets for cancer therapy. Anticancer Agents Med. Chem 13:502-514; 2013.

[95] Desouki, M. M.; Kulawiec, M.; Bansal, S.; Das, G. M.; Singh, K. K. Cross talk between mitochondria and superoxide generating NADPH oxidase in breast and ovarian tumors. Cancer Biol. Ther. 4:1367-1373; 2005.

[96] Graham, K. A.; Kulawiec, M.; Owens, K. M.; Li, X.; Desouki, M. M.; Chandra, D.; Singh, K. K. NADPH oxidase 4 is an oncoprotein localized to mitochondria. Cancer Biol. Ther. 10:223-231; 2010.

[97] Roy, D.; Cai, Q.; Felty, Q.; Narayan, S. Estrogen-induced generation of reactive oxygen and nitrogen species, gene damage, and estrogen-dependent cancers. J. Toxicol. Environ. Health B Crit. Rev. 10:235-257; 2007.

[98] Han, D.; Antunes, F.; Canali, R.; Rettori, D.; Cadenas, E. Voltage-dependent anion channels control the release of the superoxide anion from mitochondria to cytosol. J. Biol. Chem. 278:5557-5563; 2003.

[99] Schiff, R.; Reddy, P.; Ahotupa, M.; Coronado-Heinsohn, E.; Grim, M. Hilsenbeck, S. G.; Lawrence, R.; Deneke, S.; Herrera, R.; Chamness, G. C. Fuqua, S. A.; Brown, P. H.; Osborne, C. K. Oxidative stress and AP-1 activity in tamoxifen-resistant breast tumors in vivo. J. Natl. Cancer Inst. 92:1926-1934; 2000.

[100] Ito, K.; Hirao, A.; Arai, F.; Takubo, K.; Matsuoka, S.; Miyamoto, K.; Ohmura, M.; Naka, K.; Hosokawa, K.; Ikeda, Y.; Suda, T. Reactive oxygen species act through p38 MAPK to limit the lifespan of hematopoietic stem cells. Nat Med 12:446-451; 2006.

[101] Manalo, D. J.; Rowan, A.; Lavoie, T.; Natarajan, L.; Kelly, B. D.; Ye, S. Q.; Garcia, J. G.; Semenza, G. L. Transcriptional regulation of vascular endothelial cell responses to hypoxia by HIF-1. Blood 105:659-669; 2005.

[102] Gordon, M. S.; Mendelson, D. S.; Kato, G. Tumor angiogenesis and novel antiangiogenic strategies. Int. J. Cancer 126:1777-1787; 2010.

[103] Semenza, G. L. Hypoxia-inducible factors: mediators of cancer progression and targets for cancer therapy. Trends Pharmacol. Sci. 33:207-214; 2012.

[104] Wang, M.; Kirk, J. S.; Venkataraman, S.; Domann, F. E.; Zhang, H. J.; Schafer F. Q.; Flanagan, S. W.; Weydert, C. J.; Spitz, D. R.; Buettner, G. R.; Oberley, L. W. Manganese superoxide dismutase suppresses hypoxic induction of hypoxiainducible factor-1alpha and vascular endothelial growth factor. Oncogene 24:8154-8166; 2005.

[105] Connor, K. M.; Subbaram, S.; Regan, K. J.; Nelson, K. K.; Mazurkiewicz, J. E.; Bartholomew, P. J.; Aplin, A. E.; Tai, Y. T.; Aguirre-Ghiso, J.; Flores, S. C. Melendez, J. A. Mitochondrial $\mathrm{H}_{2} \mathrm{O}_{2}$ regulates the angiogenic phenotype via PTEN oxidation. J. Biol. Chem. 280:16916-16924; 2005.

[106] Ushio-Fukai, M.; Nakamura, Y. Reactive oxygen species and angiogenesis: NADPH oxidase as target for cancer therapy. Cancer Lett. 266:37-52; 2008.

[107] van Uden, P.; Kenneth, N. S.; Rocha, S. Regulation of hypoxia-inducible factor1alpha by NF-kappaB. Biochem. J. 412:477-484; 2008.

[108] Gonzalez-Perez, R. R.; Xu, Y.; Guo, S.; Watters, A.; Zhou, W.; Leibovich, S. J. Leptin upregulates VEGF in breast cancer via canonic and non-canonical signalling pathways and NFkappaB/HIF-1alpha activation. Cell. Signalling 22:1350-1362; 2010.

[109] Spirina, L. V.; Kondakova, I. V.; Choynzonov, E. L.; Chigevskaya, S. Y.; Shishkin, D. A.; Kulbakin, D. Y. Expression of vascular endothelial growth factor and transcription factors HIF-1, NF- $\mathrm{KB}$ expression in squamous cell carcinoma of head and neck; association with proteasome and calpain activities. J. Cancer Res. Clin. Oncol. 139:625-633; 2013.

[110] Place, T. L.; Domann, F. E. Prolyl-hydroxylase 3: evolving roles for an ancient signaling protein. Hypoxia 1:13-17; 2013.

[111] Aggarwal, B. B.; Shishodia, S.; Takada, Y.; Banerjee, S.; Newman, R. A.; BuesoRamos, C. E.; Price, J. E. Curcumin suppresses the paclitaxel-induced nuclear factor-kappaB pathway in breast cancer cells and inhibits lung metastasis of human breast cancer in nude mice. Clin. Cancer Res. 11:7490-7498; 2005.

[112] Barzegar, A.; Moosavi-Movahedi, A. A. Intracellular ROS protection efficiency and free radical-scavenging activity of curcumin. PLoS One 6:e26012; 2011.

[113] Bernard, D.; Quatannens, B.; Begue, A.; Vandenbunder, B.; Abbadie, C. Antiproliferative and antiapoptotic effects of cRel may occur within the same 
cells via the up-regulation of manganese superoxide dismutase. Cancer Res. 61:2656-2664; 2001.

[114] Schafer, F. Q.; Buettner, G. R. Redox environment of the cell as viewed through the redox state of the glutathione disulfide/glutathione couple. Free Radic. Biol. Med. 30:1191-1212; 2001.

[115] da Silva, M. M.; Sartori, A.; Belisle, E.; Kowaltowski, A. J. Ischemic preconditioning inhibits mitochondrial respiration, increases $\mathrm{H}_{2} \mathrm{O}_{2}$ release, and enhances $\mathrm{K}^{+}$transport. Am. J. Physiol. Heart Circ. Physiol 285:H154-162; 2003.

[116] Micalizzi, D. S.; Farabaugh, S.; Ford, H. L. Epithelial-mesenchymal transition in cancer: parallels between normal development and tumor progression. J. Mammary Gland Biol. Neoplasia 15:117-134; 2010.

[117] Gilmore, A. P. Anoikis. Cell Death Differ. 12(Suppl. 2):1473-1477; 2005.

[118] Kamarajugadda, S.; Cai, Q.; Chen, H.; Nayak, S.; Zhu, J.; He, M.; Jin, Y.; Zhang, Y.; Ai, L.; Martin, S. S.; Tan, M.; Lu, J. Manganese superoxide dismutase promotes anoikis resistance and tumor metastasis. Cell Death Dis 4; $2013 e 504$ 4; 2013.

[119] Burdick, A. D.; Davis 2nd J. W.; Liu, K. J.; Hudson, L. G.; Shi, H.; Monske, M. L.; Burchiel, S. W. Benzo(a)pyrene quinones increase cell proliferation, generate reactive oxygen species, and transactivate the epidermal growth factor receptor in breast epithelial cells. Cancer Res. 63:7825-7833; 2003.

[120] Ma, C.; Lin, H.; Leonard, S. S.; Shi, X.; Ye, J.; Luo, J. Overexpression of ErbB2 enhances ethanol-stimulated intracellular signaling and invasion of human mammary epithelial and breast cancer cells in vitro. Oncogene 22:5281-5290; 2003.

[121] Valko, M.; Rhodes, C. J.; Moncol, J.; Izakovic, M.; Mazur, M. Free radicals, metals and antioxidants in oxidative stress-induced cancer. Chem. Biol. Int 160:1-40; 2006

[122] Mori, K.; Shibanuma, M.; Nose, K. Invasive potential induced under longterm oxidative stress in mammary epithelial cells. Cancer Res. 64:7464-7472; 2004.

[123] Huber, M. A.; Azoitei, N.; Baumann, B.; Grünert, S.; Sommer, A.; Pehamberger, H.; Kraut, N.; Beug, H.; Wirth, T. NF-kappaB is essential for epithelialmesenchymal transition and metastasis in a model of breast cancer progression. J. Clin. Invest. 114:569-581; 2004.

[124] Chua, H. L.; Bhat-Nakshatri, P.; Clare, S. E.; Morimiya, A.; Badve, S.; Nakshatri, H. NF-kappaB represses E-cadherin expression and enhances epithelial to mesenchymal transition of mammary epithelial cells: potential involvement of ZEB-1 and ZEB-2. Oncogene 26:711-724; 2007.

[125] Min, C.; Eddy, S. F.; Sherr, D. H.; Sonenshein, G. E. NF-kappaB and epithelial to mesenchymal transition of cancer. J. Cell. Biochem. 104:733-744; 2008.

[126] Vizoso, F. J.: González, L. O.: Corte, M. D.: Rodríguez, J. C.; Vázquez, J.; Lamelas, M. L.; Junquera, S.; Merino, A. M.; García-Muñiz, J. L. Study of matrix metalloproteinases and their inhibitors in breast cancer. Br. J. Cancer 96:903-911; 2007.

[127] Rezaei, M.; Friedrich, K.; Wielockx, B.; Kuzmanov, A.; Kettelhake, A.; Labelle, M.; Schnittler, H.; Baretton, G.; Breier, G. Interplay between neural-cadherin and vascular endothelial-cadherin in breast cancer progression. Breast Cancer Res. 14:R154; 2012.

[128] Bae, Y. K.; Kim, A.; Kim, M. K.; Choi, J. E.; Kang, S. H.; Lee, S. J. Fibronectin expression in carcinoma cells correlates with tumor aggressiveness and poor clinical outcome in patients with invasive breast cancer. Hum. Pathol. 44:2028-2037: 2013

[129] Tsang, J. Y.; Au, S. K.; Ni, Y. B.; Shao, M. M.; Siu, W. M.; Hui, S. W.; Chan, S. K.; Chan, K. W.; Kwok, Y. K.; Chan, K. F.; Tse, G. M. P-cadherin and vimentin are useful basal markers in breast cancers. Hum. Pathol. 44:2782-2791; 2013.

[130] Chaturvedi, P.; Gilkes, D. M.; Wong, C. C.; Kshitiz Luo, W.; Zhang. H.; Wei, H. Takano, N.; Schito, L.; Levchenko, A.; Semenza, G. L. Hypoxia-inducible factordependent breast cancer-mesenchymal stem cell bidirectional signaling promotes metastasis. J. Clin. Invest. 123:189-205; 2013.

[131] Ranganathan, A. C.; Nelson, K. K.; Rodriguez, A. M.; Kim, K. H.; Tower, G. B.; Rutter, J. L.; Brinckerhoff, C. E.; Huang, T. T.; Epstein, C. J.; Jeffrey, J. J.; Melendez, J. A. Manganese superoxide dismutase signals matrix metalloproteinase expression via $\mathrm{H}_{2} \mathrm{O}_{2}$-dependent ERK1/2 activation. J. Biol. Chem. 276:14264-14270; 2001.

[132] Nelson, K. K.; Ranganathan, A. C.; Mansouri, J.; Rodriguez, A. M.; Providence, K. M.; Rutter, J. L.; Pumiglia, K.; Bennett, J. A.; Melendez, J. A. Elevated sod2 activity augments matrix metalloproteinase expression: evidence for the involvement of endogenous hydrogen peroxide in regulating metastasis. Clin. Cancer Res. 9:424-432; 2003.

[133] Connor, K. M. Hempel, N.; Nelson, K. K. Dabiri, G.; Gamarra, A.; Belarmino, J.; Van De Water, L.; Mian, B. M.; Melendez, J. A. Manganese superoxide dismutase enhances the invasive and migratory activity of tumor cells. Cancer Res. 67:10260-10267; 2007.

[134] Saari, H.; Sorsa, T.; Lindy, O.; Suomalainen, K.; Halinen, S.; Konttinen, Y. T. Reactive oxygen species as regulators of human neutrophil and fibroblast interstitial collagenases. Int. J. Tissue React. 14:113-120; 1992.

[135] Rajagopalan, S.; Meng, X. P.; Ramasamy, S.; Harrison, D. G.; Galis, Z. S. Reactive oxygen species produced by macrophage-derived foam cells regulate the activity of vascular matrix metalloproteinases in vitro: implications for atherosclerotic plaque stability. J. Clin. Invest. 98:2572-2579; 1996.

[136] Zhang, H. J.; Zhao, W.; Venkataraman, S.; Robbins, M. E.; Buettner, G. R.; Kregel, K. C.; Oberley, L. W. Activation of matrix metalloproteinase-2 by overexpression of manganese superoxide dismutase in human breast cancer MCF-7 cells involves reactive oxygen species. J. Biol. Chem. 277:20919-20926; 2002.

[137] Holley, A. K.; Kiningham, K. K.; Spitz, D. R.; Edwards, D. P.; Jenkins, J. T.; Moore, M. R. Progestin stimulation of manganese superoxide dismutase and invasive properties in T47D human breast cancer cells. J. Steroid Biochem. Mol. Biol. 117:23-30; 2009.

[138] Yodkeeree, S.; Ampasavate, C.; Sung, B.; Aggarwal, B. B.; Limtrakul, P. Demethoxycurcumin suppresses migration and invasion of MDA-MB-231 human breast cancer cell line. Eur. J. Pharmacol. 627:8-15; 2010.

[139] Tsuyada, A.; Chow, A.; Wu, J.; Somlo, G.; Chu, P.; Loera, S.; Luu, T.; Li, A. X.; Wu, X.; Ye, W.; Chen, S.; Zhou, W.; Yu, Y.; Wang, Y. Z.; Ren, X.; Li, H.; Scherle, P.; Kuroki, Y.; Wang, S. E. CCL2 mediates cross-talk between cancer cells and stromal fibroblasts that regulates breast cancer stem cells. Cancer Res. 72:2768-2779; 2012.

[140] Kahlos, K.; Pääkkö, P.; Kurttila, E.; Soini, Y.; Kinnula, V. L. Manganese superoxide dismutase as a diagnostic marker for malignant pleural mesothelioma. Br. J. Cancer 82:1022-1029; 2000. 